\title{
Determinations of system justification versus psychological reactance consumer behaviours in taboo markets
}

Article

Accepted Version

Badewi, A. A., Eid, R. and Laker, B. (2023) Determinations of system justification versus psychological reactance consumer behaviours in taboo markets. Information Technology \& People, 36 (1). ISSN 0959-3845 doi:

https://doi.org/10.1108/ITP-12-2018-0555 Available at https://centaur.reading.ac.uk/102225/

It is advisable to refer to the publisher's version if you intend to cite from the work. See Guidance on citing.

To link to this article DOI: http://dx.doi.org/10.1108/ITP-12-2018-0555

Publisher: Emerald

All outputs in CentAUR are protected by Intellectual Property Rights law, including copyright law. Copyright and IPR is retained by the creators or other copyright holders. Terms and conditions for use of this material are defined in the End User Agreement.

www.reading.ac.uk/centaur 
Central Archive at the University of Reading

Reading's research outputs online 


\section{EEmerald Information Technology}

\section{Determinations of System Justification versus Psychological Reactance Consumer Behaviours in Taboo Markets}

\begin{tabular}{|r|l|}
\hline Journal: & Information Technology \& People \\
\hline Manuscript ID & ITP-12-2018-0555.R3 \\
\hline Manuscript Type: & Article \\
\hline Keywords: & $\begin{array}{l}\text { Online shopping < Phenomenon, Qualitative method < Method, } \\
\text { Individual < Level of analysis, End users < People, Theory building < } \\
\text { Theory, Interview < Data }\end{array}$ \\
\hline \multicolumn{2}{|l}{} \\
\hline
\end{tabular}




\title{
Determinations of System Justification versus Psychological Reactance Consumer
}

\author{
Behaviours in Taboo Markets
}

\begin{abstract}
Purpose- This research aims to understand the determinants of consumers' behaviour and motivations to buy taboo items online. Two theoretical lenses, theories of psychological reactance and system justification, are invoked to frame the role of online shopping in shaping consumer behaviour in taboo markets.

Design/methodology/approach- a Naturalistic Inquiry paradigm was used to test a sample of 34 Saudi women who were buying taboo products online.

Findings- The determinant of such behaviour is based on differences in understanding the ritual restrictions between people, their society, and their country. The four principal attitudes towards restrictions are justifying, accepting, rejecting, and reacting. These attitudes frame five motivations: satisfying the restriction, to be unique, but aligned with social norms; breaking social norms; aligning one's self-image to liberal societies; and joy in challenging legal restrictions. The motives for online shopping are justification/utilitarian, to accommodate other restrictions in going to local markets; and reactance hedonic, to break restrictions. These motivations create seven different patterns of online shopping behaviour.

Originality/Value- This research contributes to the literature by presenting an alternative perspective on online shopping motivations for taboo products. Furthermore, this research calls for a new socio-psychological theory for understanding the role of technology in influencing consumer behaviour in restrictive societies.
\end{abstract}

Keywords: Shopping; Online Shopping; Restrictive Society; Saudi Arabia; Qualitative Analysis

\section{Introduction}

Taboos, which combine the forbidden with attractiveness, have captivated human interest for decades (Bataille, 1962). A taboo refers to a prohibition of a particular behaviour or conversation (Sabri et al., 2010). Taboo markets are places which sell products that are socially or legally prohibited. Generally, taboo markets are not morally or socially accepted. Examples include trading in alcohol and other drugs, sex work, gambling, baby-selling, paid domestic labour, care work, human blood, organs, eggs, sperm, genetic material, viaticals, and pollution rights. However, the fact remains that taboo products are widely bought and consumed (Sabri, 2017). Marketers intentionally aim to de-stabilise and restabilise moralities to make their products accepted and sell more (Gollnhofer, 2015). Accordingly, researchers are criticised for taking up matters that are esoteric at best and distasteful at worst: the 'dark side' of consumer behaviour (Hirschman, 1991). Traditionally, it was believed that 'core social practices and cultural values, ideas, aspirations and identities are defined and oriented in relation to consumption' (Slater, 1997, p. 24). However, obsessive, addictive, and even compensatory consumption linger under the 
umbrella of taboo. Consumption of these taboos is linked to the satisfaction of taboo desires (Elliott, 2014) and its unique motivations, such as the expression of a sense of freedom or excitement (Yalkin \& Veer, 2018).

The relationship between information technology and taboo markets is not new, but the advent of todays' technology gives a safe space in which to simulate and to practise the services sold in the taboo markets. For instance, technology-mediated sexual interaction (TMSI) (i.e. the exchange of sexual material via computer and Internet technologies (Courtice \& Shaughnessy, 2017)) is viewed as an online environment for sexual activism that takes place within its 'safe' space (Veer \& Golf-Papez, 2018). According to Veer \& Golf-Papez (2018), this technology gives the informants the opportunity to practise sex that is free from social judgments, awkwardness, embarrassment and the troubles of initial sexual contact.

Taboo markets are universal in the sense that the unacceptability of these products is global and not specific to any particular context. In Finland, where the market is experiencing a phase of drastic liberalisation, the market for sex toys still has an appreciable degree of ambivalence towards the forces that structure it (Piha et al., 2018). In this liberal context, Piha et al. (2018) found that consumers retain a felt need to manage such a sexual matter in privacy. For this reason, online shopping, even in this context, is the primary enabling vehicle for selling these products. Mostly in these cases, taboo markets are universally controversial and globally unaccepted. However, some products can be taboo in a context where people in a particular country can easily question whether the taboo is right or not. Here, technology could play a significant role in questioning, accepting, rejecting or reacting to the definition of the taboo. This research aims to investigate the role of online marketing in shaping consumer behaviour in country-specific taboo markets.

This research will ask how information technology and online shopping technologies, in particular, may enable people to justify or react in other ways to socially and regulatory restrictions on buying and using commodities. This research examines women's online shopping behaviour in a restrictive, religious, and male-dominated society that insists on specific dress codes. Gender, in this research, posits a layer of norms and operates as a pattern of social arrangements (Connell, 2010), while religion posits behavioural expectations (Petriglieri, 2020). Consumers' online shopping behaviour is the outcome of various normative pressures and attitudes towards them (Arli et al., 2020). This research will develop a framework to define and set a possible relationship between the determinants of the justifications of and reactions to the restrictions, the motivations to use online shopping, and the consequent behaviour. 
Dismantling the context-based taboo market reveals that the taboo is operationalised in three pillars of restrictions: legal, social, and individual ones. Consumer restriction is defined in this research as a physical, social and psychological prohibition of buying and using certain products in a certain place. For instance, in Islamic countries, a woman need not cover her hair in the company of her female friends, but in a non-segregated community, where men and women are in the same place, she must cover her hair with a Hijab. Without this, in many Islamic communities, she may feel embarrassed and awkward. Similarly, wearing a short skirt or short sleeves is always socially unaccepted in many rural communities (whether for women only or non-segregated).

Women over the centuries have grown used to living with these traditions can accept them because they never see women in other countries behaving differently. Thus, they have no chance to question these restrictions. But in the online shopping context, such traditions become questionable.

People's attitudes towards restrictions and the perceptions of their community (subjective norms) direct their behaviour and reflect their acceptance or rejection of such rules. Coping mechanisms in such a restrictive regime can be passive (mere acceptance) or active (contravening these stringent rules). Thus, in countries that enforce restrictions on freedom of choice, the reaction of the individual may be predicted by two theories: system justification theory (rationalising the restrictions) (Owuamalam \& Spears, 2020) and psychological reactance theory (attempting to break the restrictions) (Brehm \& Cole, 1966). The literature on consumer behaviour and motivations under restrictions covers a range of contexts (Bublitz et al., 2010; Moore \& Fitzsimons, 2014; Pezzuti et al., 2015).

Restrictions could be imposed by the seller (Moore and Fitzsimon, 2014), the government (Pezzuti et al. 2015), society (Bublitz et al. 2010), or self-belief (Ji \& Wood, 2007). Religious restrictions are unlike any of these, especially if they are enforced by state agents. The case for a religious state which presents itself as ruling in the name of God is different from any discussed in the previous literature. Saudi Arabia established religious police to enforce in public the practice of Islamic values such as gender segregation in workplaces and shops, ways of dressing in public, opening and closing times for shops (e.g., the specific times for prayer each day), what fashions may be sold in shops and how they may be sold. The risk of disobeying the state's religious orders could have a stronger influence on human behaviour than the risk in a secular state. Although it is not a topic that has yet been studied in the literature, the present research aims to gauge the role of technology in the behaviour of consumers living in a restrictive society that is controlled by a theocratic government. Through this understanding, the consumer behaviour in the environment of such a society can be better understood, modelled, and predicted. Accordingly, the research 
questions are: "What in a restrictive society determines psychological reactance and system justification?" and "How do differences in the attitudes towards restrictions affect the online shopping behaviour of a restrictive society?"

This research offers three main contributions to knowledge.: first, a bundle of explanations about the role of information technology in reshaping the dynamics of aspects of taboo marketing (Eid and Trueman, 2002; Sabri \& Obermiller, 2012; Veer \& Golf-Papez, 2018; Yalkin \& Veer, 2018). This study is among the first studies dedicated by means of socio-psychological theory to understanding the role in shopping motivation behaviour of the relationship between people and their beliefs and a restrictive society with its prevailing beliefs . It is the first to use system justification and psychological reactance to capture and investigate the motivation and determinants of online shopping in a restrictive environment. This novel perspective may help information technology specialists to understand consumer behaviour in a restrictive society and trace people's motivation to buy, more for socio-psychological reasons than to meet any physical need.

\section{Background}

The laws and practices of Saudi Arabia, traditionally, are based on religion. Its original establishment in 1744 was mainly for a religious purpose: to unite Arab tribes in the Arabian Peninsula in order to promote the Wahabi interpretation of Islam. In 1940, not long after the full establishment of the kingdom and unification of different states under one monarchy in 1932, the religious police were instituted to enforce the application of the Wahabi perspective of Islam in public. Following the precepts of Wahabism, Islamic values enforce the segregation of women and men in all public places (e.g., shops, schools and the like, public transport, and restaurants). Their function is also to ensure that women dress according to the "appropriate" code, covering not only their hair but also their faces, and instead of coloured clothes, wear only black. In the offline environment of shopping, stores must close at times of prayer. Since the 1940s, the strictness of the rules and judgments has fluctuated in line with the political environment. In 1979, after the Islamic revolution in Iran, the Saudi Arabian monarchy sensed a threat of the influence that the Saudi regime might be exposed to from that country's Islamic expansion. Before this time, the Saudi people were not strictly controlled in matters of dress, the cinema, and women's role in society. Afterward, however, religious power expanded to influence everyday Saudi life by instilling an alternative religious ideology behind Iran's ideological stance. However, these conditions changed again in 2016, as the Crown Prince Muhammed Bin Salman described on 24 $4^{\text {th }}$ October 2017: 
"The awakening project (i.e., the rule of the religious police in restricting the freedom of the society) spread in the region after 1979, for many reasons. We were not like this before; we are only returning to what we were, to Islam that is open to all religions, traditions and peoples. And we will eradicate the remnants of extremism very soon, and I do not think that this constitutes a challenge, as we represent the tolerant, moderate, and correct values, and the truth is with us in everything we face."

From 1979, then, the religious police had unrestricted power to shut down all cinemas and genderunsegregated fashion shows, extensive control over the content of magazines (i.e., how women were dressed), and women's ability to move anywhere out of doors in the absence of a male guardian. In this period, women were forbidden to travel, drive, have a bank account, and choose fashions different from the dress code of the religious police. They had to wear a Niqab, a covering for the face, hair, and body. Women were also not allowed to vote in elections or wear makeup. At the time of this research inquiry (2015), Saudi Arabia was the only country in the world where women were forbidden to drive (Greenberg, 2014). As an example of the radical difference between the market for fashion between Saudi and Western cultures, a law was passed in June 2015 banning fashion shows of all kinds in Saudi Arabia (Variyar, 2015). The World Economic Forum recently ranked Saudi Arabia $146^{\text {th }}$ of 153 countries for gender equality (Crotti et al., 2019). Before 2017, Saudi women faced restrictions unlike those in any other country. The situation has changed through the initiatives of Crown Prince Muhammed Bin Salman. When the present data were collected, however, the laws were enforced by the religious police.

Despite the state-imposed restrictions on fashion, spending on women's clothes in Saudi Arabia is substantial (14\% of all online purchases); the third most popular website in the country is a Saudi one selling Western fashion (Richards, 2013). Online sales from the USA and UK to Saudi Arabia in 2016 reached $\$ 60$ million (Bohnhoff, 2017) . This context of study offers a rich environment for understanding the actions of the state in enforcing a level of religious policing that affects the freedom of women to dress and choose for themselves what to wear. Online shopping may be a vehicle by which these religious-state restrictions may be justified or reacted against by buying online from Western countries. The present research offers a new perspective from which to understand this unique location-based taboo market (i.e., it is forbidden in Saudi Arabia but allowed everywhere else in the world) and define the motivations of its online shoppers in using technology.

\footnotetext{
${ }^{1}$ https://www.youtube.com/watch?v=ChAqsVBazMw\&ab channel=AlArabiya\%D8\%A7\%D9\%84\%D8\%B9\%D8\%B1\%D8\%A8 $\underline{0 \mathrm{D} 9 \% 8 \mathrm{~A} \% \mathrm{D} 8 \% \mathrm{~A} 9}$
} 


\section{Literature Review}

This section first critically examines the literature on the motivations for using online shopping. Then, because the existing literature pays little attention to restrictive environments, the second subsection considers theories which may assist our understanding of these motivations in such societies.

\subsection{Motivations in shopping online}

Utilitarian and hedonic motivations are the two main incentives for shopping online (Arnold \& Reynolds, 2003). Utilitarian shopping is described as task-related, rational, and determined by practical and objective considerations (for example, quality and convenience) (Picot-Coupey et al., 2021). Shopping can be described in terms of "shopping as work" (Babin et al., 1994). In other words, products are often purchased because they are needed, rather than out of enjoyment of shopping in itself (Scarpi et al., 2014). Babin et al. (1994) affirmed that such shopping is deliberate; decisions tend to be carefully evaluated and efficient. This perspective views the consumer as a "logical problem solver" (Holbrook \& Hirschman, 1982). Widespread internet access makes online shopping at any time easy and convenient. Hedonic shoppers, by contrast, seek pleasure in shopping (Eid, 2005; Scarpi, 2020). Enjoyment and expressive value can be felt and enjoyed when shopping by interacting with the situation, according to Arnold and Reynolds (2003). They identify several types of hedonic shopping motivation, including adventure (seeking difference or stimulation), gratification (shopping to mitigate stress), role (providing gifts or pleasure to others), value (the enjoyment of finding bargains and discounts), social (maintaining or enhancing relations) and idea shopping (getting to know new trends and products). Hedonic motivation also includes the feelings of freedom (Wolfinbarger \& Gilly, 2001) and the authority and status conferred by customised services and recommendations (To et al., 2007). While hedonic and utilitarian experiences can be derived from shopping, the results are likely to differ in line with the product purchased and the shopping channel used (Li et al., 2020). Fashion, in particular, is described as a high-hedonic product group because of its representative empirical and attractive content (Sebald \& Jacob, 2020).

Both the hedonic and utilitarian motivations to shop online are found to affect shoppers' behaviours. For instance, Chang, Chih, Liou, \& Yang, (2016), from a sample of 866 Taiwanese eshoppers, inferred that hedonic value and utilitarian value affected cognitive attitudes (i.e. cognitive trust and perceived risk) in turn affected perceived satisfaction and purchase intention. But the hedonic and utilitarian motivations are not based on the technological factors of the device or the platform; social pressure can play a significant role in positing the subjective definition of 
the hedonic or utilitarian motivations. Wu, Huang, Chen, Davison, \& Hua, (2018) studied 272 shoppers from a Chinese website and found that hedonic and utilitarian values fully mediate the relationship between social value and purchase intention.

However, social values and norms play a more significant role in defining the consumer motivations in conservative markets than those in liberal markets. In emerging countries, especially those under restrictive regimes such as Saudi Arabia, these hedonic and utilitarian motivations may be questioned. Given the restrictions applied to Saudi women in public, shopping offline presents many challenges that may encourage them to shop online. Indeed, their motivation to shop online is expected to diverge from that of women in more liberal countries.

\subsection{Motivations in taboo shopping online}

The motivation to use technology in taboo markets posits another layer in understanding online consumer behaviour in this context. It can be divided into the attempt to meet desires without being noticed or to express oneself freely. In the 1920s, American Tobacco reimagined cigarettes as 'torches of freedom' when it sought to counter the proscriptions on women's smoking and thus expand its markets (Amos \& Haglund, 2000). Piha et al. (2018), in their study of sexual therapists, sexual advisors, and clinical sexologists so as to understand the online shopping behaviour of buying sex toys in Finland, found that increased sexual satisfaction and feelings of excitement at destroying societal taboos appear to be the primary motivators of such purchase intentions. Another study by Veer and Golf-Papez (2018) found that the primary motivator in buying technology-mediated sexual encounters was expressing oneself online and satisfying one's desires freely and safely, without being observed by society. Online settings usually offer a safe space for buying taboos without being embarrassed in so doing. The emancipatory nature of perceived anonymity online permits shoppers to express themselves in a manner they feel they cannot work in an offline setting (Mano, 2021).

In the taboo markets, the rejection of these products is usually universal, which makes the motivation mainly a desire to taste freedom or to buy a product and use it in secret. What if the taboo product is defined by a certain geographic location (as Saudi Arabia is, being the only country which so restricts the female fashion market and women's behaviour in public, regarding their clothing and shopping), while members of the Saudi community can see through online stores that others with similar values and norms do not define these things as taboo and can buy them? 


\subsection{Theoretical Stances}

The enforcement of conformity is the single most important means by which cultural factors affect consumer behaviour in any environment. Thus, socio-psychological theorists state that aspiring to conformity pushes people to echo the behaviour of their peer group, with corresponding societal norms. Conversely, there is potential for actively resisting cultural norms, particularly when individuals feel pressured to conform, causing more active resistance (Venkatesan, 1966). The personal need to adjust to conformity generally affects customers' attempts to create different consumption styles (Hemetsberger \& Weinberger, 2012).

In countries where freedom of choice is restricted, individuals' reactions can be predicted by two theories: system justification theory (SJT), which deals with rationalising restrictions (Jost, 2020), and psychological reactance theory (PRT), referring to attempts by individuals to break restrictions (Laurin et al., 2012, 2013). System justification can be motivated partly by the epistemic need to reduce uncertainty and ambiguity; research consistent with this assertion associates the personal desire for law, structure, and termination with endorsing conservative, system-justifying attitudes. Open-mindedness and tolerance of uncertainty and ambiguity are negatively associated with such attitudes (e.g. (Chirumbolo et al., 2004; Goren et al., 2009; Jost \& Hunyady, 2003; Van Hiel et al., 2004). A growing number of studies link many of these same epistemic motives to religiosity (e.g. (Hogg, Adelman, \& Blagg, 2010; Arli et al., 2020). Saroglou (2002) reviews dozens of studies carried out in a variety of cultural contexts and notes that the correlation between religiosity and constructs pertaining to uncertainty avoidance and motivating closed-mindedness is almost always positive and statistically significant. For instance, contrasted with less religious people, those who are more religious tend to be more assertive (Altemeyer, 2002; Pratt et al., 2006), to be less tolerant of inconsistency and ambiguity (Feather, 1964), to have a greater need for personal control (Hood Jr et al., 1996), and be relatively resistant to new experiences (Saroglou, 2002).

Conversely, PRT holds that individuals are driven to restore usurped liberties and resist attempts to coerce them (Torrance \& Brehm, 2006; Wicklund, 2013). Thus, restricting freedom would be counterproductive. For example, some political attempts to reduce smoking have increased consumption because of the psychological reactance of smokers (Burton et al., 2015; Hoek, 2004). Psychological reactance theory holds that individuals will have an entirely contrary response to limitations on their freedom to that predicted by system justification theory (Laurin et al., 2013). PRT suggests that individuals are driven to replace defunct liberties and respond undesirably to attempts by others to coerce their freedom (Wicklund \& Brehm, 1967). This strand of research suggests that restricting freedom will have counterproductive repercussions. In an innovative 
study, participants assessed a record as much more needed if they were told that they had no option but to receive it as a gift or were required to choose another form instead (Brehm \& Cole, 1966; Chartrand et al., 2007; Snibbe \& Markus, 2005). Additional research found that when consumers face stockouts, as a restriction on their freedom to choose, high reactance consumers perceive these products as more desirable than those whose reactance is low (Moore $\&$ Fitzsimons, 2014). According to PRT, people respond to their constraints by placing greater worth on the object or behaviour concerned.

System justification and psychological reactance have not been used as theoretical lenses to understand and investigate the motivation in (or determinants of) online shopping in restrictive environments. This research aims to close these gaps and yield new insights for theory and practice. Accordingly, qualitative interpretive research will be used to understand in depth the relative and subjective definitions of taboos and restrictions so that the potential influence of these idiosyncratic definitions can be traced in the attitudes, motivations, and behaviours of online shopping behaviour.

\section{Methodology}

\subsection{Sampling}

This section covers four aspects of sampling. They are the sampling approach, sampling criteria, ethical considerations of sampling s, and recruitment for and administration of sampling.

First, the sampling methodology adopted in this research is approached via grounded theory (Straus \& Corbin, 1990). In this, the size of the sample is not predetermined; it is based on theory saturation. The cases are selected according to need so as to improve the saturation of the theory. The recruitment process is continuous until the thesis is validated and verified so that new cases have nothing fresh to contribute. The sampling process is summarised in Figure 1. The sample grows to 34 because the last four respondents did not contribute anything much to the theory. 


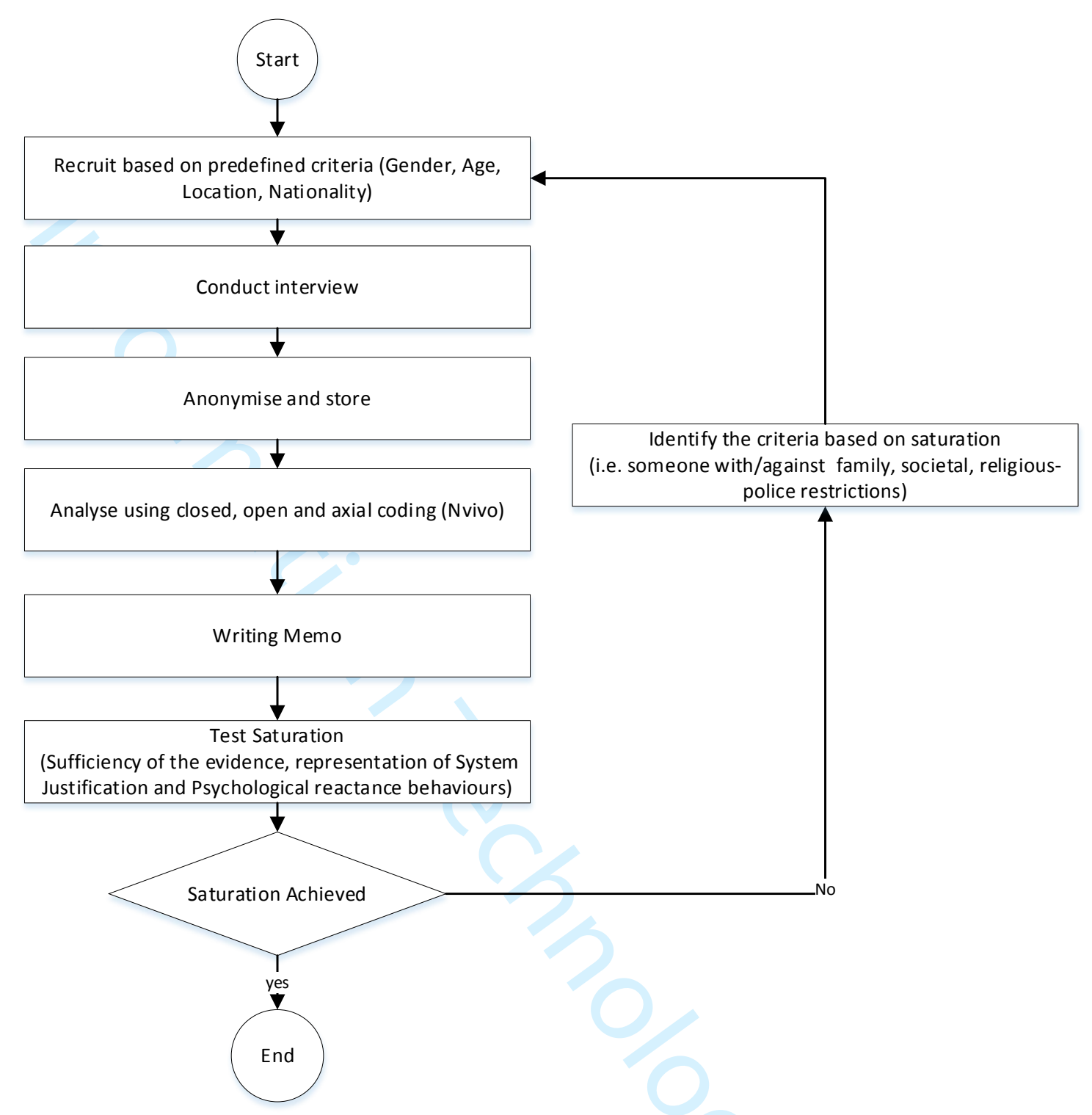

Figure 1: Sampling process

Second, the criteria for selection of the sample and its size were set by the iterative nature of the data collection and analysed by theoretical sampling (Corbin \& Strauss, 1990). This research sample does not represent the Saudi population. The purpose was to recruit women from a restrictive society who had the means and ability to shop online for a qualitative investigation of their attitudes to online shopping. The population targeted in this research was Saudi women residents in Saudi Arabia who can buy fashion online without restrictions of a psychological nature (trust in online shopping; perceived difficulties in buying fashion online) or material nature (shipping or payment problems). Men were excluded because women face considerably more restrictions, specifically in the choice of clothing (Al-Rasheed, 2013). The age range (30-49) was selected to exclude both young and older adults. Older people are more inclined to justify the status quo (Laurin et al., 2009), while teenagers and young women may be effectively controlled by their families or unduly sensitive to peer pressure (imitating friends, celebrities, or fashion icons) in their fashion behaviour (Khare et al., 2012). All the recruits had the experience of online 
shopping and bought clothes and other items online. None had any technical or trust issues with online shopping; it is known that the propensity to trust (Liu \& Tang, 2018) and perception of difficulty (Kraft et al., 2005) in using online shopping can affect attitudes and motivation. To ensure consistency and avoid the effects on attitude of living in remote or rural areas (Xu \& Paulins, 2005), all the interviews were conducted in Riyadh (the capital city of Saudi Arabia).

The third aspect is the ethical consideration in the process. The third author obtained ethical clearance from his academic institution (Number 152/2120). Ethical considerations were considered carefully due to the sensitivity of the topic. All of the individuals who participated in the interviews gave their informed consent to the interviewer before they provided any information. The interviewer ensured that no underage or vulnerable individuals who could not provide informed consent could participate in the interviews or research process (Keizer, 2017). Finally, all the interviewees were assured of complete confidentiality for their personal and identifiable data to ensure privacy was not breached. The interviewees were assured that their answers would never be used against them, nor to identify them personally, so that they felt able to provide information freely and without concerns over their privacy, confident that the research would cause no harm to the participants (Blaikie \& Priest, 2019). Finally, all the interviewees' scripts were anonymized, and the other collaborating researchers did not have access to their names.

Fourth, the sampling recruitment process was based on snowball sampling based on the predefined criteria and based on the need of the theory development process. Because of the nature of this research project, the writers could not use public websites to recruit participants; rather, personal networks were used, and respondents were asked to refer the project to others who might fit the research needs. The second author, who lives in Saudi Arabia, approached women whom she personally knew or who had been referred by other interviewees. Despite respondents being assured of their anonymity, three women refused to complete the interview. One claimed that the researcher worked for the government's intelligence system and left without completing her interview. The other interviewees were eventually satisfied and conducted their interviews without further demur, having been given confidence that the second researcher would not disclose their identity.

The interviews were conducted in Arabic and analysed in Arabic because all the researchers, except the last one, are bi-lingual (Arabic and English). English was not used because the interviews were held in Saudi Arabia, where the mother tongue is Arabic. The aim was for them to express their opinions freely without language restrictions. Moreover, translation before the final 
reporting of the analytical results could have affected the quality of the analysis, since meaning typically alters to some extent in translation.

\subsection{Interview Guide}

The focus of the interview was to set the individual's subjective definition of the taboo product, the level of acceptance or rejection of the restrictions, and the consequences for her online shopping behaviour. As summarised in Table 2, the interview started with filter questions about demographics to grasp the context of each participant. The questions concerned age, marital status, educational background, and job. Then questions were asked on the fashion restrictions followed by others to aid the understanding of online shopping motivations and behaviours and hence avoid cognitive bias. One of the motivation questions dealt with shopping for fashion: "Why do you buy fashion online?" and the second was "Why did you choose these websites or stores"? The question about behaviour asked "Which websites and which stores do you buy from?" and "How often do you shop online compared with offline shopping?"

A taboo in this context is a social definition of prohibited products and behaviours. However, this research argues that behaviour is a function of the distance between the self and the social and legal restrictions. Thus, four questions were asked to assess what each restriction meant to the participant. They were "Do you experience personal/family/social/legal restrictions? The order of the questions was carefully arranged because exposing the respondent to legal or social restrictions leads to bias when they contemplate their personal restrictions. Thus, the questions began with some on personal restrictions (which the researcher could not know in advance), then moved on to family, social and legal restrictions (which are all familiar from law and custom). At the end of the questions about each pillar, the respondents were asked about the level of agreement with the restriction and why they had agreed or disagreed. The level of the agreement indicates the level of acceptance or justification of the restriction, while the level of disagreement indicates rejection of, or reaction against the restrictions. Additionally, the question on the agreement served as a measure of validity to help the researcher understand the mental differences for the participants about the pillars of fashion restriction. The last question was on fashion behaviour in general: "Which fashions can you buy and wear in public, with friends, and with family? Why?" This functioned as a validation for the first questions and to an extent as an aid to reflection after positioning themselves within the mental pillars of the restrictions.

Table 1: Interview guide

\begin{tabular}{ll}
\hline Question & Rationale \\
\hline Do you buy fashion online? Why? & $\begin{array}{l}\text { Fashion Online Shopping } \\
\text { motivations and behaviour }\end{array}$ \\
\hline $\begin{array}{l}\text { From where? Which websites? Which stores? How often compared to } \\
\text { offline shopping? }\end{array}$ & \\
\hline
\end{tabular}




\begin{tabular}{ll}
\hline Why these websites in particular? & \\
\hline $\begin{array}{l}\text { Do you have limitations or restrictions when you buy fashion? What are } \\
\text { they? }\end{array}$ & $\begin{array}{l}\text { Definition of the interviewee's } \\
\text { self-restrictions }\end{array}$ \\
\hline $\begin{array}{l}\text { Do your family set limitations or restrictions when you buy fashion? What } \\
\text { are they? }\end{array}$ & $\begin{array}{l}\text { Definition of family and } \\
\text { societal restrictions }\end{array}$ \\
\hline $\begin{array}{l}\text { Do you think your family's restrictions are different from your self- } \\
\text { restrictions? Could you explain the differences, please? }\end{array}$ & $\begin{array}{l}\text { To validate the differences in } \\
\text { the restrictions }\end{array}$ \\
\hline $\begin{array}{l}\text { How do you see these family restrictions? } \\
\text { Do you think the family restrictions are different from what you have? } \\
\text { could you explain? (if not aligned, what if you break these restrictions?) }\end{array}$ & $\begin{array}{l}\text { Definition of family and } \\
\text { societal restrictions }\end{array}$ \\
\hline $\begin{array}{l}\text { How do you see these societal fashion restrictions? are you with it, not } \\
\text { very happy, and wish to change and why? }\end{array}$ & $\begin{array}{l}\text { Definition of the societal and } \\
\text { societal restrictions }\end{array}$ \\
\hline $\begin{array}{l}\text { Do you think the societal restrictions are different from what you have? } \\
\text { could you explain? (if not aligned, what if you break these restrictions?) }\end{array}$ & $\begin{array}{l}\text { To validate the differences in } \\
\text { the restrictions }\end{array}$ \\
\hline $\begin{array}{l}\text { What are things not allowed by the religious police? } \\
\text { How do you compare your buying and using fashion restrictions with } \\
\text { those of your family, society, and the religious police? }\end{array}$ & $\begin{array}{l}\text { Definition of the societal and } \\
\text { societal restrictions }\end{array}$ \\
\hline $\begin{array}{l}\text { Which fashions can you buy and wear in public, with friends, and with } \\
\text { family? Why? }\end{array}$ & $\begin{array}{l}\text { Attitudes towards the } \\
\text { restrictions }\end{array}$ \\
\hline
\end{tabular}

\subsection{Data analysis}

The data were analysed thematically using Nvivo (Maher et al., 2018). Closed coding searches for known phenomena, using theory as a sensitising tool; open coding seeks to understand new themes; and axial coding connects the data between codes (Reichertz, 2007). Here, closed coding was used to classify interviewees as reacting against or justifying restrictions. Acceptance of societal restrictions is a complex phenomenon. The sample needed to represent a variety of views on these restrictions. According to Kay et al. (2009), system justification behaviour and attitude are coded by statements defending and giving rationales for the societal and legal restrictions. Reactive behaviour is coded by statements that reflect anger over lost freedom or the feeling that one's freedom is being restricted (Knight et al., 2014). Any comment reflecting an attack on fashion restrictions was considered a sign of psychological reactance behaviour. Open coding was used to define the behaviour, and axial coding was used to associate the behaviour with the attitude.

As summarised in Table 2, when the sampling process ended, five justifiers (i.e., justifying the restrictions), twelve acceptors (i.e., accepting the restrictions), twelve deniers (i.e., rejecting the restrictions), and five rebels (reacting against the restrictions) had emerged.

Table 2: Summary of codes

\begin{tabular}{ccc}
\hline $\begin{array}{l}\text { Code (Closed } \\
\text { Coding) }\end{array}$ & $\begin{array}{l}\text { Motivations to buy online } \\
\text { (Open Coding) }\end{array}$ & Main Shopping Behaviour (Open Coding) \\
\hline $01 \mathrm{~J}-05 \mathrm{~J}$ & Justifying & Buying local fashion online \\
\hline $01 \mathrm{~A}-02 \mathrm{~A}$ & To be unique & Buying Islamic clothes from Arabic (Islamic) websites and tailoring them \\
\hline $03 \mathrm{~A}-05 \mathrm{~A}$ & To be unique & $\begin{array}{c}\text { Buying Islamic clothes from Arabic (Islamic) tailors' websites and } \\
\text { wearing them at home (female only events) }\end{array}$ \\
\hline
\end{tabular}




\begin{tabular}{|c|c|c|}
\hline $\begin{array}{l}\text { Code (Closed } \\
\text { Coding) }\end{array}$ & $\begin{array}{l}\text { Motivations to buy online } \\
\text { (Open Coding) }\end{array}$ & Main Shopping Behaviour (Open Coding) \\
\hline $06 \mathrm{~A}-07 \mathrm{~A}$ & $\begin{array}{c}\text { To be unique } \& \\
\text { To break social rules }\end{array}$ & $\begin{array}{c}\text { Buying Islamic clothes from Arabic (Islamic) websites and wearing them } \\
\text { at home (female only events) and in public } \\
\text { Buying Western and Arabic Clothes to wear them in women events }\end{array}$ \\
\hline $08 \mathrm{~A}-09 \mathrm{~A}$ & $\begin{array}{l}\text { To be unique } \& \\
\text { To break social rules }\end{array}$ & $\begin{array}{l}\text { Buying Islamic clothes from Arabic (Islamic) websites and tailoring them } \\
\text { Buying modest fashions from international websites and tailoring them } \\
\text { Buying Western fashion and wearing them at events for women only }\end{array}$ \\
\hline $10 \mathrm{~A}-11 \mathrm{~A}$ & $\begin{array}{l}\text { To break social rules \& To } \\
\text { attach the self-image to } \\
\text { Western liberal society } \\
\end{array}$ & $\begin{array}{l}\text { Buying modest fashions from Western websites and tailoring them } \\
\text { or wearing them in public (as long as they complied with legal rules) } \\
\text { Buying Western clothes and wearing them at events for women only }\end{array}$ \\
\hline $01 \mathrm{D}-05 \mathrm{D}$ & To break social rules & $\begin{array}{c}\text { Buying fashions from Arab Countries and wearing them in public } \\
\text { Using a detachable Niqab and loose Hijab } \\
\text { Buying Western clothes and wearing them at events for women only }\end{array}$ \\
\hline $06 \mathrm{D}-10 \mathrm{D}$ & $\begin{array}{l}\text { To attach the self-image to } \\
\text { Western liberal society }\end{array}$ & $\begin{array}{l}\text { Buying modest fashions from Western websites and tailoring them } \\
\text { Buying standard Western fashions and wearing them but covering the hair } \\
\text { (Using a detachable Niqab and loose Hijab) } \\
\text { Buying Western clothes and wearing them at events for women only }\end{array}$ \\
\hline$\frac{11 \mathrm{D}-12 \mathrm{D}}{01 \mathrm{R}-07 \mathrm{~J}}$ & $\begin{array}{l}\text { The joy of breaking } \\
\text { restrictions and Aligning } \\
\text { the self-image to Western } \\
\text { liberal society }\end{array}$ & Buying Western clothes and wearing them in public \\
\hline
\end{tabular}

\subsection{Aspects of research quality}

There are five research quality aspects used in this study, the first four of which pertain to trustworthiness (Guba, 1981). The final aspect is concerned with the applicability of this research in different contexts (i.e. 'generalisability'). Given that data are collected from people and understood by people. In recognition that human nature is inherently subjective in understanding and presenting ideas, the four aspects are reliability, validity, credibility, and reflexivity. Reliability designates the degree to which participants can be relied upon to be truthful in telling their definitions of constraints, opinions, feelings, emotions, and attitudes (Marshall \& Rossman, 1999). Because of the sensitivity of this topic, it was essential to ensure a safe space for the respondents enabling them to speak honestly. It was believed that the participants might give false information and misrepresent what they believed in if they felt threatened, under observation, or shy about expressing their ideas forthrightly (Kirk \& Miller, 1986). Accordingly, different measures were adopted to guarantee the integrity of the interview and a safe space where the participants could speak freely.

As summarised in Table 3, the second aspect was the validity, whether the participant's intended meaning had been correctly apprehended (Kirk \& Miller, 1986). To be sure of this, during the interviews, the interviewer intermittently paraphrased the respondent's stated answers to check that the interviewer grasped the meaning that had been intended. After writing memos, the 
interviewer called the interviewees to summarise the main points she had addressed in their interviews.

Credibility is the third aspect that was stressed in this research. It denotes the degree to which the transcribed records of its findings are correct and trustworthy, making no blunders in reporting annotations or scripts (Lincoln \& Guba, 1990). To this end, all the interviews were stored temporarily for use in the research (except where specifically forbidden by participants) and transcribed to ensure integrity in reporting the findings. The final aspect was reflexivity, i.e., the level of trustworthiness in deriving this research framework and providing that the rationale for interpreting the data was the best fit for the intended purpose of understanding the determinants of the system justification and psychological reactance behaviours reflected in the participants' online shopping. Thus, using the literature, we evaluated different potential understandings of the salient evidence and derived from these the most meaningful interpretations of the participants' definitions of restrictions and their consequent behaviours. The applicability of the research is discussed under the heading of 'Limitations' because this aspect sets boundaries of the study and possible divergence from the results when applied in other contexts.

Table 3: Research quality measures

\begin{tabular}{lll}
\hline $\begin{array}{l}\text { Research } \\
\text { Quality }\end{array}$ & Definition & Measure used \\
\hline Reliability & $\begin{array}{l}\text { Certainty that participants } \\
\text { are telling the truth and } \\
\text { their discourse is constant } \\
\text { over time. }\end{array}$ & $\begin{array}{l}\text { Asking the same question in different ways at different times. } \\
\text { Allowing participants who refused to be recorded the chance } \\
\text { to talk without recording. } \\
\text { Meeting in private spaces (i.e. locked rooms (8 interviews), } \\
\text { cafés with private areas (15 interviews), or at their home if } \\
\text { they preferred (10 interviews). }\end{array}$ \\
& $\begin{array}{ll}\text { Showing a consent form to confirm that all the data gathered } \\
\text { were confidential and would not be shared with anyone. } \\
\text { Trying to help them feel relaxed }\end{array}$ \\
& $\begin{array}{l}\text { Certainty that the } \\
\text { understanding of the } \\
\text { researcher matches that of } \\
\text { participants. }\end{array}$ & $\begin{array}{l}\text { Paraphrasing the answers and checking their acceptability } \\
\text { with the participant. } \\
\text { Emails were sent to confirm the content of the interviews. }\end{array}$ \\
\hline $\begin{array}{l}\text { Ensuring that everything } \\
\text { written is correct, truthful } \\
\text { and trustworthy. }\end{array}$ & $\begin{array}{l}\text { Consistency of the report with few or no contradictions } \\
\text { between findings by using a recorder and recording } \\
\text { interviews, then checking the transcripts. }\end{array}$ \\
\hline $\begin{array}{l}\text { Ensuring that the } \\
\text { researcher's understanding } \\
\text { is correct and her } \\
\text { interpretations are the most } \\
\text { suitable in the context. }\end{array}$ & $\begin{array}{l}\text { Evaluating different possible understandings of the facts } \\
\text { using the literature review and other rationales. }\end{array}$ \\
\hline
\end{tabular}




\section{Findings and Analysis}

Four main themes emerge from this research which help to explain the variations in online shopping behaviour and motivation in this taboo market. The four themes are the definition of restriction, different attitudes towards restriction (justifying, accepting, rejecting, and reacting), motivations to buy online, and online shopping behaviours. The summary of codes and their definitions are in Table 4 and visualised in figure 2. The following section sets the definition of 'restriction' while the following sections detail certain attitudes towards the restrictions, explaining the effect on shopping behaviour.

Table 4: Definition of codes

\begin{tabular}{|c|c|}
\hline \multicolumn{2}{|c|}{ Code Definition } \\
\hline Definition of Restriction & $\begin{array}{l}\text { It is a perceived limitation of the freedom which comes when the personal } \\
\text { values are less conservative than the social or state values }\end{array}$ \\
\hline Attitude towards restrictions & It is an attitude of the person towards the limitation of the freedom to .... \\
\hline 1. Justifying & defend and rationalize the importance of its existence. \\
\hline 2. Accepting & conform it without resistance. \\
\hline 3. Rejecting & $\begin{array}{l}\text { refuse it without acting against the limitations, rather have a tendency to be } \\
\text { different from others }\end{array}$ \\
\hline 4. Reactance Against & $\begin{array}{l}\text { Aggressively restore the perceived forgone freedom by taking counter-action } \\
\text { against the restriction. }\end{array}$ \\
\hline Motivations to buy online & The driver to shopping for fashion online is to ....... \\
\hline $\begin{array}{l}\text { 1. Satisfying the self- } \\
\text { restriction }\end{array}$ & $\begin{array}{l}\text { comply with the enforced restrictions and see online shopping as a way of } \\
\text { expressing religious belief (women should not go outdoors to shop in the } \\
\text { market). }\end{array}$ \\
\hline $\begin{array}{l}\text { 2. To be unique but socially } \\
\text { acceptable (fashionable) }\end{array}$ & $\begin{array}{l}\text { differentiate oneself from one's peers while respecting social and state } \\
\text { restrictions }\end{array}$ \\
\hline $\begin{array}{l}\text { 3. To be unique but infringing } \\
\text { on social values }\end{array}$ & $\begin{array}{l}\text { differentiate oneself from others by flouting social values but not daring to } \\
\text { violate state rules }\end{array}$ \\
\hline $\begin{array}{l}\text { 4. To attach the self-image } \\
\text { with other liberal societies }\end{array}$ & mimic liberal societies as a reflection of one's rejection of the restrictions. \\
\hline $\begin{array}{l}\text { 5. Joy of breaking the legal } \\
\text { restriction }\end{array}$ & $\begin{array}{l}\text { have the pleasure of violating state and social restrictions by breaking them } \\
\text { in public. }\end{array}$ \\
\hline Shopping Behaviour & It is the deliberate action to get ....... \\
\hline 1. Buying Local Fashion & Traditional clothes from local online websites \\
\hline $\begin{array}{l}\text { 2. Buying Islamic clothes } \\
\text { from Islamic liberal } \\
\text { countries and tailoring } \\
\text { them to wear in public }\end{array}$ & $\begin{array}{l}\text { Buying from Islamic countries which allow less conservative values, tailoring } \\
\text { the purchases to be unique but still acceptable to society and the state }\end{array}$ \\
\hline $\begin{array}{l}\text { 3. Buying Islamic clothes } \\
\text { from Islamic liberal } \\
\text { countries to wear at home }\end{array}$ & $\begin{array}{l}\text { Buying fashion items from Islamic countries without tailoring them to wear } \\
\text { them at home, breaking the social taboos but not the state's. }\end{array}$ \\
\hline $\begin{array}{l}\text { 4. Buying modest fashion } \\
\text { items from Western } \\
\text { countries and tailoring } \\
\text { them to wear at home }\end{array}$ & $\begin{array}{l}\text { Buying western but modest fashion items and tailoring them to be distinctive } \\
\text { while accommodating the social and state taboos in wearing them at home. }\end{array}$ \\
\hline $\begin{array}{l}\text { 5. Buying modest fashion } \\
\text { from Western countries use } \\
\text { at home }\end{array}$ & $\begin{array}{l}\text { Buying Western but modest fashion items and wearing them at home to self- } \\
\text { attach to liberal societies differentiate themselves and violate the social, but } \\
\text { not state. }\end{array}$ \\
\hline
\end{tabular}


6. Buying Western non- Buying Western fashion items and wearing them at home intentionally modest clothes and wearing obliterate the social taboos, but not the state. them at home

7. Buying Western - nonmodest - clothes and wearing them in public
Buying Western fashion items and wearing them in public to intentionally attack the social and state taboos

\subsection{Definition of restrictions}

The level of perceiving the restriction as a "taboo" is to see it as one of the "cultural productions embedded socially and historically' (Sabri et al., 2010, p. 62). In religious communities, Jafari \& Süerdem (2012) group the definition of the restriction among the (re)interpretations of religious guidelines; while these are different, everyone refers a taboo back to relevant spiritual texts, as a transcendental set of guidelines. In the present research, this argument is evident since all Islamic fashion restrictions can be traced back to this text:

And tell the believing women to lower their gaze (from looking at forbidden things) and protect their private parts (from illegal sexual acts, etc.) and not to show off their adornment except only that which is apparent and to draw their veils all over Juyubihinna and not to reveal their adornment except to their husbands, their fathers, their husband's fathers, their sons, their husband's sons, their brothers or their brother's sons, or their sister's sons, or their women (i.e. their sisters in Islam), or the (female) slaves whom their right hands possess, or old male servants who lack vigour, or small children who have no sense of the shame of sex. And let them not stamp their feet so as to reveal what they hide of their adornment. And all of you beg Allah to forgive you all, O believers, that you may be successful.

\section{Chapter 24, Verse 31, the Light (Sorat El-Noor)}

As shown in Table 5, the restrictions are divided into three main categories based on who interprets this verse. These are self-restrictions (i.e., the level of religiosity), social restrictions (i.e., subjective norms), and legal restrictions (i.e., those capable of enforcement by the religious police). A product becomes taboo in a society when a fashion item violates the socio-legal restriction. At the same time, behaviour is determined by the position of the self and family restrictions, instead of socio-legal ones. 
Table 5: Definition of restrictions

\begin{tabular}{lll}
\hline Concept & Definition & $\begin{array}{l}\text { Dress code criteria according to the } \\
\text { respondents }\end{array}$ \\
\hline $\begin{array}{l}\text { Self- } \\
\text { restrictions }\end{array}$ & $\begin{array}{l}\text { Individual interpretation of the Qur'an and } \\
\text { Hadith }\end{array}$ & $\begin{array}{l}\text { No fixed criteria, but respondents all agree } \\
\text { the hijab is required }\end{array}$ \\
\hline $\begin{array}{l}\text { legal } \\
\text { restrictions }\end{array}$ & $\begin{array}{l}\text { Interpretation of the sources made by the } \\
\text { dominant scholars and supported by the } \\
\text { formal and informal media }\end{array}$ & $\begin{array}{l}\text { Criterion is the Niqab (in Saudi Arabia, a } \\
\text { covering for the face, hair, and body) }\end{array}$ \\
\hline $\begin{array}{l}\text { Social } \\
\text { restrictions }\end{array}$ & $\begin{array}{l}\text { Interpretation of the sources by family } \\
\text { members }\end{array}$ & $\begin{array}{l}\text { Dependent on the family's education and } \\
\text { background; criteria are not fixed }\end{array}$ \\
\hline
\end{tabular}

The first pillar of the restriction is legal. The legal restriction is defined by respected scholars in the community and reflected as a norm by the legal authorities (i.e., the religious police, in this context). This restriction differs from country to country and from area to area, debating the meaning of the phrase "that which is apparent" in the Qur'anic verses and Hadith teachings. In Egypt, for example, argue that the woman should cover her body, apart from the face and hands, in loose, opaque clothing which reveals nothing and delineates nothing sexually attractive (AlQaradawi, 1995). In most parts of Egypt, women who do not cover their hair are considered shameful and not widely accepted. In Saudi Arabia, scholars (sometimes called Wahabism or Salafism) such as Ibn Othaimin interpret the covering to include 'the palms of the hands, one eye, or both eyes, [except] for the necessity to see the way ... [and] outer dress like veils, gloves, headcovers, aprons, etc.' (Al-Albani, 2002). This interpretation is enforced in Saudi Arabia through the formal and informal media and the religious police. If any woman violates this dress code, the religious police stop her and issue a reprimand. Legal restrictions, in this context, are embodied in the actions of the religious police, who patrol public areas and challenge those whom they consider inappropriately dressed based on the state's interpretation of the Islamic sources.

The second pillar of restrictions is social restrictions, which are defined as society's judgment and evaluation of behaviour, translated as the subjective norms of the society (Morris \& Liu, 2015). In this religious and male-dominant context, women may never behave according to their own analyses. Merely talking about taboo topics is perceived as defiance (Yalkin \& Veer, 2018). Moreover, 'when market offerings conflict with religious control of non-market social institutions, believers are forced to re-evaluate what it means to be faithful' (Mittelstaedt, 2002, p.13). Accordingly, to operationalise society's restrictions, the level of the family's acceptance of female behaviour must be perceived. Family restrictions imposed by a woman's parents, husband and siblings influence the accepted dress code and unacceptable fashion choices. Their rules may be similar to or different from those of the society. Still, the family in general translates general social restrictions as what should or should not be done to protect the family's social status in the community (Edgell, 2005). The societal pressures in urban areas where the cultural identity is 
lower are also different from those in rural areas where the cultural identity is higher. In Saudi tradition, the Niqab is an obligatory part of the inherited culture.

"I wear the Niqab as others do because of the society I am living in." $05 \mathrm{~A}$

I'm not forced to wear it. But I know they are intolerant of this behaviour, and I respect that. $07 \mathrm{D}$

The third pillar represents self-restriction. Self-restrictions set the limit for each woman's freedom in line with her own interpretation of the Qur'an and the Hadith (the words of the Prophet Mohammed). Self-restriction can be operationalised as the level of a woman's religiosity in terms of the greater strictness of the restrictions that she lays on herself as a matter of closeness to God (King \& Crowther, 2004). Self-restrictions are mainly personal interpretations (or ones that follow scholarly interpretations) of what is obligatory and what is recommended in the Holy Qur'an and the Hadith. As summarised in Table 6, self-restrictions among the respondents were found to be neither fixed nor clear-cut, being based on scriptural interpretation. The legal, social, and personal interpretations interact with one another. They affect each other, being consistent in default, to create accepted norms in the society

My mother was the main reason for that. When I was young, she did not allow me to wear anything different from the Niqab. In time, it became taken for granted, and now I feel that my face is my own and not everyone is authorised to see it. $04 \mathrm{~J}$

Table 6: Differences in the criteria for self-restrictions

\begin{tabular}{|c|c|}
\hline Self- Restriction & Evidence \\
\hline $\begin{array}{l}\text { Niqab is } \\
\text { essential }\end{array}$ & $\begin{array}{l}\text { "Nothing is called a Hijab (covering the hair only); these people misinterpret the } \\
\text { Qur'anic phrase. It is the Niqab (covering the face), not the Hijab, that is a must." } 02 \\
\mathrm{~J}\end{array}$ \\
\hline $\begin{array}{l}\text { Hijab is } \\
\text { essential }\end{array}$ & $\begin{array}{l}\text { "The Hijab is a (religious) constraint. I do not wear it often. When I do wear it, I } \\
\text { pretend that I am a good Muslim. By wearing it, I also represent Islam when I travel } \\
\text { abroad. This is a great responsibility. Doing any wrong will be attributed to Islam } \\
\text { and this is a great risk." 09 D }\end{array}$ \\
\hline $\begin{array}{l}\text { Neither Hijab } \\
\text { nor Niqab is } \\
\text { essential }\end{array}$ & $\begin{array}{l}\text { To be a Muslim, it's not necessary to cover your hair, and it doesn't mean that you } \\
\text { will lose your rights in society. I can do anything I want. } 04 \mathrm{R}\end{array}$ \\
\hline
\end{tabular}

\subsection{Determination of the Psychological Reactance and System Justifications}

Online shopping motivations and behaviours varied as a result of the differences in what was accepted under the above kinds of restrictions. When (self-interpreted) religious restrictions differed from those imposed by family and friends or the state, the woman's behavioural response was to accept the restrictions or react against them. Her consequent behaviour was based on her attitude towards the enforcement of the limits. In other words, when the religious restrictions were matched with the legal ones, the attitude was to accept and thence to justify them. 


\subsubsection{Justifying the restrictions: Justifiers Behaviours.}

When someone's self-restriction is higher than the social restrictions and both are higher than the socio-legal restrictions, buying online will appear as the justification and support of internal beliefs. In this study, five women demonstrated justificatory attitudes, motivations, and behaviours. This can be seen as one attitude (wholeheartedly embracing the social and legal restrictions), one motivation (utilitarian justifying motivation), and one behavior (buying local fashion online). The primary reason to buy is to satisfy the subject's self-restriction. In this case, online shopping is perceived as a "blessing" that can help people to fulfill their interpretations of the Islamic texts, which makes them feel "safe" and "satisfied" with their choice. In this case, a woman who has a justificatory attitude towards social restrictions will be most persuaded by the utilitarian motivation to shop online. Conservative women believe that they should not go to the market, or if they must visit them, they must be accompanied by a male. This belief is aligned to the fatwa ${ }^{2}$ of an influential Saudi Islamic scholar, to the effect that visiting markets is not recommended for women. Although such interpretations are not accepted by everyone (Hussein 1953; Ahmed 1992), many religious women in Saudi Arabia accept them. This research found that when a woman or her family believes that women must be accompanied by a male - which is not a legal requirement - they shop online because it is consistent with their beliefs.

"Women should be accompanied by a male companion. It is forbidden to go to the market alone. Online shopping gives me the opportunity to buy without the feeling of sin or obliging a male relative to take me shopping" $02 \mathrm{~J}$

"Buying online is better and more convenient for me than traditional shopping. My family and I believe that I have to be accompanied when I go shopping. Finding someone to give me a lift to the market is not at all easy. Shopping online made me happier" 03J

\footnotetext{
${ }^{2}$ The Urban Dictionary defines a fatwa as "any religious decision made by a mufti (Islamic scholar who is an interpreter or expounder of Islamic law)."
} 


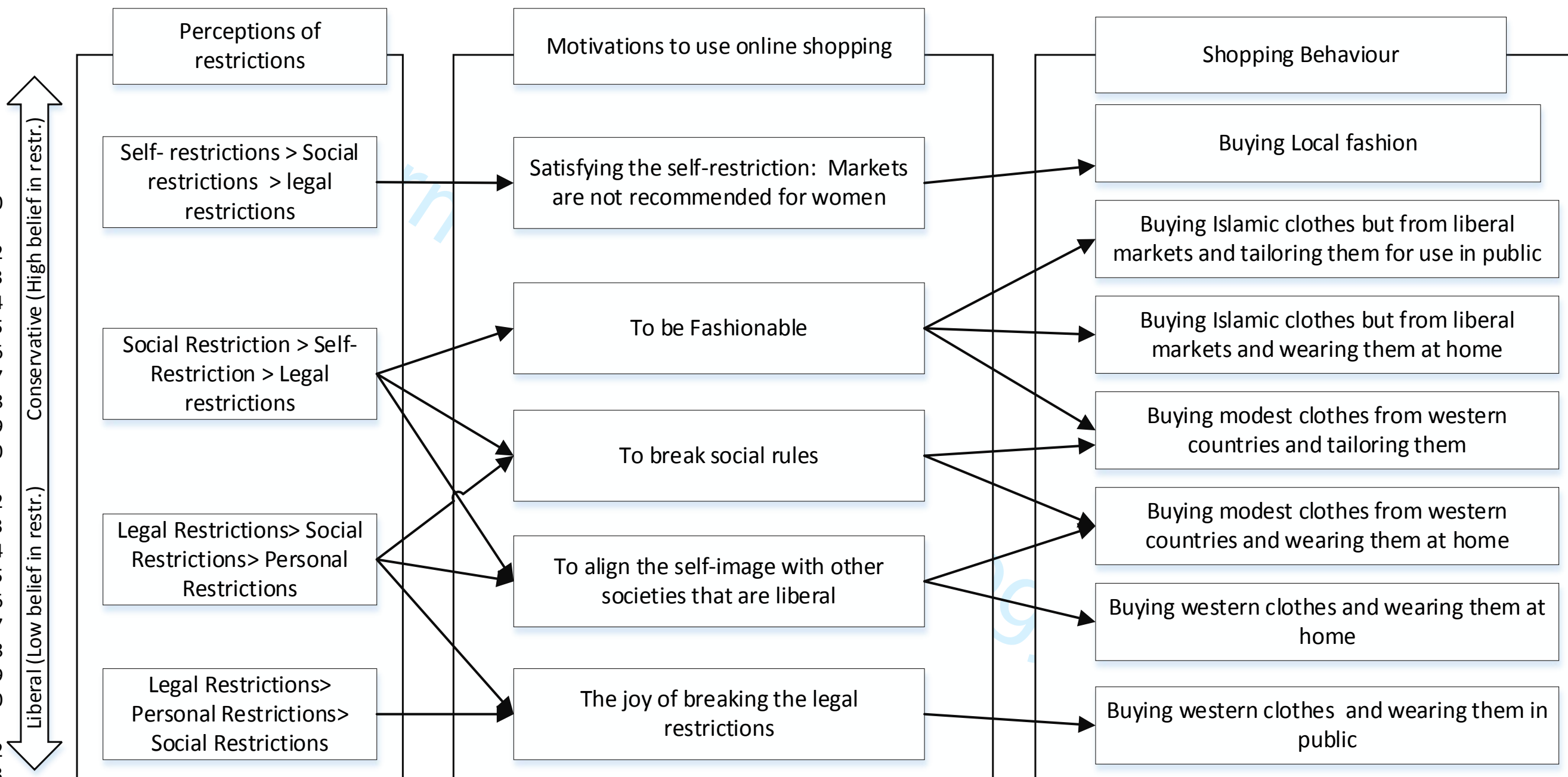


Table 7: Examples of themes

\begin{tabular}{|c|c|c|c|c|}
\hline $\begin{array}{l}\text { Perceptions of } \\
\text { Restrictions }\end{array}$ & Evidence & $\begin{array}{l}\text { Motivations to use } \\
\text { online shopping }\end{array}$ & Shopping behaviour & Evidence \\
\hline $\begin{array}{l}\text { Self }>\text { Social }> \\
\text { Legal }\end{array}$ & $\begin{array}{l}\text { "the Niqab is a must, no question, not the } \\
\text { Hijab ... The religious police are actually } \\
\text { right. They are doing a very good job to } \\
\text { protect our society." } 01 \mathrm{~J}\end{array}$ & $\begin{array}{l}\text { Justifying (i.e. } \\
\text { Markets are not } \\
\text { preferred for } \\
\text { women) }\end{array}$ & $\begin{array}{l}\text { Buying Saudi } \\
\text { traditional Niqab } \\
\text { online to avoid } \\
\text { commuting to } \\
\text { markets }\end{array}$ & $\begin{array}{l}\text { "I don't like markets ... They're not recommended from the } \\
\text { Islamic point of view because women and men mingle in } \\
\text { one place. Lots of Islamic violations happen. Women are } \\
\text { not properly dressed and talk goes on between males and } \\
\text { females. O1J } \\
\text { "Now online shopping really makes life easier and fits more } \\
\text { with my religious values (not going outside much and } \\
\text { staying at home most of the time). } 05 \mathrm{~J}\end{array}$ \\
\hline $\begin{array}{l}\text { Social }>\text { Self }> \\
\text { Legal }\end{array}$ & $\begin{array}{l}\text { "I respect my father and mother's } \\
\text { traditions, when I go to (where I live). I } \\
\text { wear the Niqab." } 09 \mathrm{~A}\end{array}$ & To be unique & $\begin{array}{l}\text { buying or } \\
\text { customising Islamic } \\
\text { but non-Saudi } \\
\text { fashion and wearing } \\
\text { it in safe places or } \\
\text { customising it to be } \\
\text { socially safe. }\end{array}$ & $\begin{array}{l}\text { "I prefer online for buying fashions that are not available } \\
\text { in the Saudi market [such as] T-shirts and trousers for our } \\
\text { female meetings and parties." } 09 \mathrm{~A} \\
\text { "Before, I used to follow Lebanese fashion magazines; now, } \\
\text { I prefer the internet as long as it can fit my religious } \\
\text { requirements. I buy the fashions that I can re-model later } \\
\text { with my tailor to fit my requirements." } 01 \mathrm{~A}\end{array}$ \\
\hline $\begin{array}{l}\text { Social }> \\
\text { Legal }>\text { Self }\end{array}$ & $\begin{array}{l}\text { "Uncovering the face is not forbidden. } \\
\text { Religion eases our lives rather than } \\
\text { making them difficult. However, our } \\
\text { society makes it a must and it becomes } \\
\text { more of a national tradition than a } \\
\text { religious requirement. I comply with these } \\
\text { requirements as a matter of respect, not } \\
\text { because I believe in them" } 04 \mathrm{D}\end{array}$ & $\begin{array}{l}\text { To break social } \\
\text { rules (attach } \\
\text { themselves to } \\
\text { Western societies) }\end{array}$ & $\begin{array}{l}\text { Buying modest } \\
\text { fashion from } \\
\text { Western markets or } \\
\text { normal Western } \\
\text { fashion but } \\
\text { customising it to fit } \\
\text { with minimum } \\
\text { accepted legal } \\
\text { requirements }\end{array}$ & $\begin{array}{l}\text { "Modest means long sleeves and skirts. They offer fantastic } \\
\text { designs from international fashion designers." } 04 M H A \\
\text { "I love buying my fashion from NY Dress as it has 'modest' } \\
\text { options." 05D } \\
\text { "I don't buy online from BHS Saudi Arabia. I buy from } \\
\text { other European branches of BHS. I never buy from the } \\
\text { Saudi shops." } 18 D \\
\text { "I love to design my fashion. I don't enjoy wearing } \\
\text { traditional Saudi clothes. I love to be unique and no one } \\
\text { else wears what I wear." IOD }\end{array}$ \\
\hline $\begin{array}{l}\text { Legal }>\text { Self }> \\
\text { Social }\end{array}$ & $\begin{array}{l}\text { "I wear what I want to wear. these } \\
\text { religious people are like dogs barking in } \\
\text { the street" } 02 \text {. } \\
\text { "My mother always says that I am a rebel, } \\
\text { not like other girls who fear others ... I am } \\
\text { a rebel. However, my rebellion is against } \\
\text { what is wrong. I do what I believe in. I } \\
\text { never do anything I do not believe in." } \\
04 R\end{array}$ & $\begin{array}{l}\text { To challenge the } \\
\text { legal rules }\end{array}$ & $\begin{array}{l}\text { Buying Western } \\
\text { fashions and wearing } \\
\text { them in public }\end{array}$ & $\begin{array}{l}\text { "I buy unique and different fashion items online. I hate } \\
\text { these restrictions which are barbaric, imposed by the } \\
\text { religious police here. These restrictions will be changed } \\
\text { sooner or later" } 02 \text { R } \\
\text { "I do not wear the Hijab and Niqab in public. I do not care } \\
\text { much. The society has to change and accept others. It will!! } \\
\text { It is a matter of time. We have to be positive and not passive } \\
\text { in accepting restrictions" } 04 R\end{array}$ \\
\hline
\end{tabular}




\subsubsection{Accepting restrictions: Acceptors}

Among the respondents in this research 12 were acceptors demonstrating one attitude, three motivations and four behaviours. When social restrictions are higher than one's self-restriction and both are higher than the legal one, a woman will not be able to deviate far from the subjective norms set by her peers, family members, and neighbours. An average woman in a religious and male dominant society re-evaluates what it means to be a good Muslim and the related norms of gender. She presents a socially acceptable, exploratory self that seeks to understand, express and delve more deeply into accepting the restrictions (Yalkin \& Veer, 2018).

However, the attractions of online shopping come to such women in two forms: "To be unique but aligned with social norms", and "to align the self-image with other societies that are liberal". Thus, women in this category buy online from Islamic liberal markets but wear the clothes among their friends (i.e. breaking the social rules but not in public), or buy clothes from the West but with the intention of customising and modifying them to fit their values or of wearing these clothes at home with friends to be distinctive. Women in this category are self-conflicted: they do not believe much in the restrictions, but everybody around them does believe in them. Online shopping is the gate to escape from this situation by buying online Western fashions, which must not be worn in public, but customising and wearing them whenever they can in free and safe circumstances (i.e. with friends who accept them). They approach online tailors to align the garments they have bought more closely with social norms, while still being distinct or even unique.

I usually can't find the required level of modesty online, so I buy something that can be tailored, then send it to the tailor to fix it. $11 \mathrm{~A}$

I go to international fashion websites. I select what appeals to me and can be customized to fit the religious needs later. I try to buy the best while respecting my religious values. 12A

I contacted a good designer who I found on Instagram. I asked her to design fashionable clothes to fit my religious needs. She shows me designs and we choose one from them. Then she customises it and makes a new Islamic version for me. 10A

The self can be aligned with buyers in other markets that are liberal through buying online from international fashion suppliers who offer 'modest' designs or designs that can be tailored. The women in this group can search using keywords such as 'modest', 'long', 'decent' or 'long-sleeved'. Another preferred method was to find websites with a reputation for modesty, such as Turkish or Jewish-background websites.

"I have some tricks to deal with international fashion. For example, Marks \& Spencer always have modest options because it is a Jewish oriented company. Thus, most of what is offered can be aligned to our values, at least at female parties." $08 \mathrm{~A}$ 
"I follow up Turkish websites; they always introduce what is new before any local shop. My sister and I always buy from them. As you know, Saudi Arabia is too hot to shop here easily. Thus, I love to buy from them." $06 \mathrm{~A}$

\subsubsection{Rejecting restrictions: Deniers}

This study found 12 respondents who were deniers. These women demonstrated one attitude, three motivations and six different behaviours. When the legal restriction is higher than the social and selfrestrictions and the social restrictions are higher than the self-restriction, there is a tendency to reject the restrictions and use online shopping for hedonic motivations in terms of "breaking social rules", "aligning the self-image to those in other societies that are liberal" and the "joy of breaking the legal restrictions". The women falling into this category have a stigmatised self; this self is one valued as a contained space through imitating the fashion worn in liberal societies which presents the self to an in-group that bolsters the self rather than separating it from other selves (Crocker \& Knight, 2005). The theme that is brought out here for the first time is the "joy of breaking legal restriction" though it is not a major element at this level of acceptance of restriction. However, it can be noted among women who are used to living far away from their families and working women.

"I wear whatever I like to wear. I am mature enough and I can do whatever I want... These clothes (referring to the Hijab and Niqab) are barbaric and they have to know they are traditions and not part of Islam (from her definition of the self-restriction). When I see the religious police coming towards me and they can do nothing, I sense victory" $04 \mathrm{D}$

"I respect my father and mother's traditions, so when I go to (where I live) I wear the Niqab. But when I go back to Riyadh (the capital city), I take it off and I wear the fashions that I buy online from the UK or the USA as long as they are accepted as parts of a professional dress code" $06 \mathrm{D}$

\subsubsection{Reaction against restrictions: Rebels}

In this study 5 rebels described their motivation. They had one main attitude, one motivation and one behaviour. When the social and self-restrictions are much lower than the legal restrictions, there is a strong negative perception of the restriction as "tough", "Islamist", "terrorist" and "barbaric" .

I don't believe the Niqab is a religious requirement. I feel it is a barbaric traditional requirement; there are different Qur'anic interpretations of the fashion-related verses. 03LA

Indeed, it seems that all the five women who fell into this category were buying their clothes only from Europe and the USA and always refer to people with a different outlook as "you" in a way that reflects their perception of being different with a different identity and different values. They always refer to "your" or "Saudi" values and beliefs. This can be a reaction to being stigmatised, because it is a way of differentiating one group from another but it is also a way of assigning attributes to the stigmatised and their subsequent separation and loss of status (Goffman, 1984). These women always separate these beliefs from themselves and they feel aggressive towards the religious police. 
Some describing them as "dogs barking in the street" and "intervening in private life". Their motivation to buy is hedonic, namely, "aligning the self-image with those in other societies that are liberal" and "challenging restrictions"

"My family and I used to live in the USA. We see these restrictions as barbaric and they do not make sense to me. Too much restriction makes me fed up. You know, I sometimes buy online "provocative" fashion to challenge and to exasperate the religious police" $02 R$

These women buy online directly from Western shops and wear the clothes as they are without tailoring or modification. They buy non-modest fashion and they feel happy to challenge society in doing this. They believing that this behaviour could change their society

"I am not the one who shall be changed. I buy and wear these fashion because I know that this will change the society and they have to accept me as a human not as a salve" $05 \mathrm{~J}$

\section{Discussion and Conclusion}

This research makes three major contributions to knowledge; its definition of taboo markets, the role of technology in reshaping the dynamics of this market, and the use of technology in this market to predict consumer behaviours.

Traditionally, "taboo products" are defined by each society; the political and social liberalisation process of Western societies has destroyed certain taboos (Manceau \& Tissier-Desbordes, 2006). This research defined 'taboo' in a religious society, as the logic of the scholars dominating this society in interpreting spiritual texts, which is endorsed and enforced by the legal system, and has been normalised and integrated in society's value system over time. This research argues that a taboo product is operationalised as the interaction between the three pillars of restrictions. This supports the finding by Piha et al. (2018) that consumer behaviour is a reaction to various societal, constructed and individual pressures. However, this research adopts a different perspective in defining the elements of pressure in a theocratic society, which focuses on the differences between the pillars of the restrictions. The three pillars of restrictions are the government's theocratic restrictions, society's restrictions, and self-interpreted religious restrictions. The first are the rules inspired by the government's understanding of the religious texts, while society's restrictions are the perceptions of the community concerning right and wrong actions, based on the society's understandings of the same scripts. The third restriction stems from the way in which individuals interpret the religious texts. In other words, all restrictions have a similar source but may lead to different interpretations and the level of differences in interpretation creates levels of religiosity shown in what women wear and how they adopt different fashion styles. This implies that changes in the way that these religious scripts are interpreted could revolutionise and radicalise the society's values, norms, and behaviours. 
The literature on the taboo market focuses on whatever can be done out of sight. However, the present research focuses only on taboo fashions which are perceived externally and internally, and are easily visible to social and legal eyes for their judgement. Thus, the second contribution is defining the determinants of the behaviours in online taboo markets. In the literature, it is widely accepted that age, gender and religiosity could be strong predictors of behaviour under restrictions. This research found that the perceptions and differences in the three pillars of restrictions are the key determinants of attitudes, motivations and behaviours. When self-restriction is the highest, there will be a positive justificatory attitude towards restrictions, which leads to a utilitarian motivation to shop online in order to buy local Saudi fashions from local markets. When social restrictions are highest, there will be a negative attitude to social restriction but respect may colour the attitude due to the nature of this society. Thus, the hedonic motivation in this case will vary from "being unique", "breaking social norms in as socially safe a way as possible", and "aligning the self-image to that of Western societies". Because the social norm is strong, all of these motivations will be reflected in socially safe zones. For instance, wanting to be unique will be reflected in buying Islamic fashion but not from Saudi Arabia, breaking social norms will be reflected by buying Arabic fashions that are not aligned with the legal system but wearing them to private female-only events. Aligning the selfimage to Western fashion will be achieved through tailoring these fashions to fit in if possible with legal requirements or wearing them to private family events only. When the legal restriction is the highest, women may show strong reactance behaviour if their restrictions of their society are lower than the legal restrictions and their self-restriction. This will incite them to wear Western fashion in public, covered either by a detachable Niqab or a loose Hijab (i.e. a garment which they can take off when the religious police are not watching); or they can take it off and challenge the legal system; or they may even feel joy in challenging them.

The third contribution is the role of technology in reframing the dynamics of this market. The literature judges the marketers and advertisers to be the main agents in the process by triggering the desires and emotions of freedom in potential customers (Veer \& Golf-Papez, 2018). This research agrees with the assertion, but augments it by clearly showing that the equation has two parts. It is not only the advertiser who is the key driver here, but also the readiness of the clients to accept the advertising messages. In this research, we found that women whose personal values were higher than the societal and legal values tended to justify the current system; indeed, they may be offended by such "violating" messages. In any case, without information technology, women would have no access to the Western or Arab fashion markets, and would not perceive themselves as different or as susceptible to something that triggered their reactive behaviour. The internet was a critical vehicle for empowering women to behave in this way; it made them feel different (not needing to follow the 
herd) and enabled them to break social rules and rebel by buying clothes from abroad. Thus, for those who reject such restrictions, virtual shopping can be seen as a vehicle of liberation and reaction and also as a vehicle of alignment for those who believe in and justify the restrictions. Because of the restrictions on Saudi women's movements, those who accept such restrictions argue that online shopping is the best way to buy clothes.

\subsection{Theoretical Implications}

This research comes up with three main theoretical implications, regarding: the role of technology in defining the restrictions and the taboo markets; the investigation of the relationship between the ideology, technology and consumer behaviour; and congruity theory in relation to online shopping.

First, this research uses socio-psychological theory to provide a novel perspective for understanding the role of the relationship between the beliefs of the individual and those of the society on the motivation for shopping behaviour in a restrictive society. Taboo markets are those defined by the way in which others (i.e. societies and governments) define accepted and prohibited products (i.e. other people's restrictions and definitions). The perception of restrictions, as in psychological reactance theory, have been covered in social research for the sake of understanding the role of legal restrictions on purchasing behaviour (Laurin et al., 2012). This research contributes to the literature by offering a detailed perspective from which to understand why adverse reactions to restrictions appear in some, while others may justify them. The new perspective developed in this research seeks the reason for the variation in the differences in the perception of the restrictions, which is derived from the relationship between the societal, personal, and family's beliefs and values. This research borrows from the socio-political literature for concepts to apply to the taboo markets to explain how this perception of the constellation of restrictions (societal, family, legal and personal) influence each other to ultimately elicit different motivations to buy. The motivations may justify the restrictions, accept them, reject them or react against them. These different motivations are reflected in the respondents' buying/shopping behaviour.

Second, this research sets the foundation for a new theory in understanding the role that technology can play in consumer behaviours in the taboo markets of restrictive societies. Restrictions are not necessarily concerned with what women wear but also how they behave and are perceived in society. Questions can come to underline how these women must negotiate their experience of freedom freedom to shop, choose, pay, and wear the items they purchase. A new theory is required to formulate and set the foundation for understanding the interaction and interplay between different 
actors in a society and how they may influence the values and restrictions on consumer behaviour. EMarketing should not be absent from the sociological changes in societies. Marketing science ought to understand a society's behaviour and the underlying reasons for it. The interactions between cultural identity, religiosity, and the perception of restrictions can be a clue to understanding the role that IT can play in directing consumer motivation and behaviour, especially in restrictive societies. Online shopping in the virtual stores in other Islamic countries can enable people to see others who hold similar values (i.e., believe in the same religion) but observe different levels of restriction (i.e. accepting the need to cover the hair but not the face, as in Egypt; or not covering the hair but being modest, as in Tunisia) which encourage them to question their social and religious restrictions because a change in their self-restriction is possible. One of the main factors determining the motivation to justify restrictions is the perception that one has the "ability" to break them. Now that women can buy online from anywhere in the world, society's power to buy may be reshaped. This determines the designs that will be available in the market; it has implications for the family (i.e., that males must accompany a woman out shopping, which affects her decision making) and for the law (i.e., the country's acceptance of selling or prohibiting an item); everyone, in fact down to the woman who can with a few clicks buy whatever she wants online. Online shopping will change the taboo markets over time, because more and more women will change their behaviours and construct new norms in the market.

Third, besides the call to develop a new socio-psychological theory with which to understand the role of technology in driving consumer behaviour in restrictive societies, there are other academic implications. This research, supported by others (El-Bassiouny, 2015; Jafari \& Sandikci, 2016), offers evidence that ideology should be added to the list of factors to consider in consumer behaviour. International markets are segmented within as well as between cultures and one must understand the diversity of the drivers of consumer behaviour underlying this segmentation, in order to categorise individual consumers not only according to their psychological and social needs and behaviours (Wedel \& Kamakura, 2012), but also by their ideologies. El-Bassiouny, (2015) believes the market to be segmented by levels of religiosity; this research helps to segment a market not only by wellknown demographic, situational or behavioural factors (Hofacker, 2001), but also by the level of cultural identity, in line with Sia et al., (2009). It does so by the extent of justification or reaction visà-vis existing restrictions, since shopping online for fashion shows each segment behaving differently. This clearly confirms Lusch and Vargo's results that highlight the fact that "value is always uniquely and phenomenologically influenced by the beneficiary" and is also idiosyncratic, experiential, contextual and meaning-laden (Lusch \& Vargo, 2011). 
Fourth, this research opens the way to researching congruity theory (Tannenbaum \& Osgood, 1955) from a different perspective. In cultural studies, congruity is said to occur where the country of origin of a brand is matched with the language of the brand name. An example would be Volkswagen, the German name of a brand of cars built in Germany. Incongruity, where the language and country of origin are different (Salciuviene et al., 2013), is found to have a positive impact on the intention to purchase (Chao et al., 2005) and on the perception of quality (Miranda, 2020). This research suggests that consumers showing a psychological reaction to restrictions will experience a greater impact of incongruity on the intention to purchase and that this relationship is moderated by cultural identity. Conversely, justification of the restrictions and high cultural identity are proposed to have a negative impact on the incongruity between the brand name and the country of origin. All of these propositions could be used to guide the direction of empirical quantitative research.

\subsection{Practical Implications}

Successful marketing ultimately depends on understanding consumers' behaviour, attitude and perceptions so as to be able to satisfy their needs and wants (Chiu et al., 2014). This research has produced evidence that ideology, and a woman's attitude to her country's prevailing attitudes should be added to the list of factors to consider. Western companies offer fashions primarily for Western women. Therefore, in Saudi Arabia, these designs suit only those who have a relatively low level of cultural identity. Indeed, Saudi women do not buy fashions online merely to meet their physiological needs but also as a way of representing themselves among other nationalities or of reflecting their rejection of the restrictions currently imposed.

The most important point here is who influences the way in which the women, the society, and the government interpret the religious texts. Government plays a critical role in promoting certain religious voices while belittling others. For instance, the Saudi media in the age of the previous king heavily promoted the laws against women drivers, listening to music, and going to concerts. The present king has promoted religious scholars who give the same actions legitimacy and acceptance. The ideological outlook of Saudi Arabia is changing; now, for instance, the law has changed to allow women to drive. Some women started to take "secret" driving lessons to be ready for this (Ensor, 2018), influenced by some social media and the official media. In this case a legal restriction has been relaxed. But it is unclear whether it is still perceived as a religious and social restriction, especially when some influential people who were given prominence in the previous reign are still speaking against it. The new regime, it is also noticed, has curtailed the patrols of the religious police on the streets (Murray, 2018). The Niqab is now unnecessary in legal institutions (Bashraheel, 2017). However, those who influence the social media note that it can still be seen to prevail everywhere. 
In theory, nothing is clearly stated in the Qur'an about such matters. Professionals and leaders of the international fashion industry should understand the relationship between the religious influencers on the official media (as the voice of theocratic government), the religious influencers on the social media (as the voice of society), and the beliefs and views of the target segment vis-à-vis these influencers.

The designers of e-marketing should think about the implications for those who justify the system of over-revealing images of women and the suggestion of nudity, because they are offensive to conservative women and, by flouting the traditions of the community, will deter them from buying what is advertised,. But it could have a stronger impact on women who are psychologically reacting against the system. Such images will discourage these women from returning to a website or even from continuing to browse and buy goods. Professional studies should reveal the level of psychological reaction against the system before advertisers decide how to design their promotional visual messages.

It is also important to distinguish between the level of religiosity and someone's cultural identity. Cultural identity is concerned with accepting the social values and terms which may not be the same as an individual's religious values as they interpret or embrace them. Such discrepancies between the two concepts can create implications in the understanding and perception of societal restrictions.

Last but not least, restrictions influence motivation. The marketing mix (product, price, place, and promotion) of a restricted product will be more effective if it addresses a desire to rebel (i.e. motivation founded on psychological reaction). Once the restrictions are removed, the marketing mix should be adjusted to reflect changes in the motivation to purchase.

\subsection{Research Limitations}

The main methodological limitation of the present research lies in its reliance on consumer interviews as its main source of data, and sole source of its primary data. In general, effective primary research aims to use multiple data sources in order to provide higher levels of reliability and validity, and to ensure that the claims of the respondents are actually reflected in their actions. However, in the case of the present research it was not possible to achieve this degree of reliability and validity, due to having a single source of data. This limitation was addressed, to a certain extent, by the use of secondary data reports to support the interviews, and by the triangulation between the literature, the interviews and the secondary data. However, the literature and secondary data were not directly focused on in the same way as the primary data; therefore, this triangulation may not ensure reliability. 
The main data source consists only of the opinions of individual women in Saudi Arabia, which may be influenced by individual cultural, social and religious factors, and thus may not fully reflect the actual behaviour of all the women in the country. This means that the data collected in this study are a reflection of individual and group perceptions of female behaviour and online shopping which do not necessarily reflect those of all the people in Saudi Arabia and their habitual shopping.

Furthermore, this research targeted women aged between 30 and 40 years. Stafford, Turan, \& Raisinghani (2004) found that younger people were more inclined than older ones to shop online, while Passyn, Diriker, \& Settle (2016) report that respondents under 35 years of age had different perceptions of online shopping from those aged 35 to 50 or over 50 . Therefore, the applicability of the present results to other age groups is questioned and further research would be required to extend the findings to them.

Carrying out the interviews themselves also presented some challenges. Some women, despite agreeing to attend the interview and confirming the date, were unwilling to have their voices recorded because they did not want their voices to be in the possession of anyone else. Some women felt doubtful and fearful of taking part in an interview and the purposes of the research had to be clarified to them. Some women stopped in the middle of the interview and completely withdrew after responding in depth to the most frequently asked questions, in particular those relating to the effects of adhering to religion and the impact of community opinion. Some women came to the meeting in clothes of a type which differed from their usual apparel (i.e. wearing a Hijab although they did not do so in normal circumstances), because they thought it might be offensive if they did not. It was not very easy to find unveiled women to interview. In Saudi culture, it may be considered offensive to look for unveiled women and much effort was expended on finding an adequate number of them.

\subsection{Future research}

There are three main avenues for future research. First, this research was limited to females and since males tend to have stronger reactions than females do (Seemann et al., 2004), it is not clear how they would behave with regard to their fashion shopping behaviour, so this could be examined in future research. Age is also a critical factor in determining the level of reaction: the lower the age, the stronger the reaction (Hong et al., 1994). Therefore, another study might target another age-group, for example, that of 21- to 30-year-olds, where reactance is likely to be high and the interviewees have a high level of power to buy what they want. Furthermore, ethnic groups differ in their behaviour in reaction; for example, Caucasians are more reactant than African Americans, Asians or Hispanics (Woller et al., 2007). Therefore, a replication of this study on other ethnicities, say, in Israel, Turkey or Indonesia, might obtain interesting results. These countries have relatively strong cultural identity 
but varying levels of power distance. Indeed, power distance and reactance behaviour are in inverse proportion to each other. Thus, it is important to undertake follow-up research in this area, in an effort to determine whether the findings from the interview phase reported in this thesis can be supported by other data. This might be done through longer-term strategies such as observations of people's browsing and purchasing history; however, care will need to be taken when planning this research, due to the privacy restrictions around women in restrictive societies.

Second, it is imperative to admit the limitations of a qualitative study in making space for new quantitative research. Qualitative research findings are not generalizable but offer a holistic and relatively deep perspective while quantitative studies are generalisable but based purely on associations. Thus, we suggest that future research might adopt cause and effect research designs via experimental research. In particular, future experimental research in the area can consider measuring both chronic and primed responses (Lim, 2015) and the use of sophisticated methods such as neuroscientific techniques (Lim, 2018) in cost-effective experimental designs such as those informed by data partitioning techniques (Lim et al., 2019).

Third, these data were collected in 2015 before the succession of the present King. He has endorsed the work of new religious scholars, as reflected in a new legal system with no religious police and the loss of the Niqab as a legal requirement (Abdulaziz, 2019). Now the main question is whether the fashion market will change. If it will, what are the factors that will contribute to it? Who will be affected sooner (in terms of age, nature of work, nature of education, and travelling behaviour)? The answer to these questions could help international fashion brands to penetrate this rich market. 


\section{References}

Abdulaziz, D. (2019, October 2). Saudi Women Are Breaking Free From the Black Abaya - WSJ. The Wall Street Journal. https://www.wsj.com/articles/saudi-women-are-breaking-free-fromthe-black-abaya-11570008601

Al-Rasheed, M. (2013). A Most Masculine State: Gender, Politics and Religion in Saudi Arabia (1st ed.). Cambridge University Press.

Altemeyer, B. (2002). Dogmatic behavior among students: Testing a new measure of dogmatism. The Journal of Social Psychology, 142(6), 713-721.

Amos, A., \& Haglund, M. (2000). From social taboo to "torch of freedom": The marketing of cigarettes to women. Tobacco Control, 9(1), 3-8. https://doi.org/10.1136/tc.9.1.3

Arli, D., Septianto, F., \& Chowdhury, R. M. M. I. (2020). Religious But Not Ethical: The Effects of Extrinsic Religiosity, Ethnocentrism and Self-righteousness on Consumers' Ethical Judgments. Journal of Business Ethics, 1, 3. https://doi.org/10.1007/s10551-019-04414-2

Arnold, M. J., \& Reynolds, K. E. (2003). Hedonic shopping motivations. Journal of Retailing, 79(2), 77-95. https://doi.org/10.1016/S0022-4359(03)00007-1

Babin, B. J., Darden, W. R., \& Griffin, M. (1994). Work and/or Fun: Measuring Hedonic and Utilitarian Shopping Value. Journal of Consumer Research, 20(4), 644. https://doi.org/10.1086/209376

Bataille, G. (1962). Death and Sensuality: A study of Eroticism and the Taboo. Walker and Company.

Blaikie, N., \& Priest, J. (2019). Designing Social Research: The Logic of Anticipation (3rd ed.). Polity Press.

Bohnhoff, T. (2017). Digital Market Outlook: E-commerce Fashion. Statistica. https://www.statista.com/download/outlook/whiterpaper/eCommerce_Fashion_Outlook_0916.pdf

Brehm, J. W., \& Cole, A. H. (1966). Effect of a favor which reduces freedom. Journal of Personality and Social Psychology, 3(4), 420-426. https://doi.org/10.1037/h0023034

Bublitz, M. G., Peracchio, L. A., \& Block, L. G. (2010). Why did I eat that? Perspectives on food decision making and dietary restraint. In Journal of Consumer Psychology (Vol. 20, Issue 3, pp. 239-258). No longer published by Elsevier. https://doi.org/10.1016/j.jcps.2010.06.008

Burton, S., Hoek, J., Nesbit, P., \& Khan, A. (2015). "Smoking is bad, it's not cool... yet I'm still doing it": Cues for tobacco consumption in a 'dark' market. Journal of Business Research, 68(10), 2067-2074. https://doi.org/10.1016/j.jbusres.2015.03.004

Chang, S. H., Chih, W. H., Liou, D. K., \& Yang, Y. T. (2016). The mediation of cognitive attitude for online shopping. Information Technology and People, 29(3), 618-646. https://doi.org/10.1108/ITP-08-2014-0172

Chao, P., Wührer, G., \& Werani, T. (2005). Celebrity and foreign brand name as moderators of country-of-origin effects. International Journal of Advertising, 24(2), 173-192.

Chartrand, T. L., Dalton, A. N., \& Fitzsimons, G. J. (2007). Nonconscious relationship reactance: When significant others prime opposing goals. Journal of Experimental Social Psychology, 43(5), 719-726. https://doi.org/10.1016/j.jesp.2006.08.003

Chirumbolo, A., Areni, A., \& Sensales, G. (2004). Need for cognitive closure and politics: Voting, political attitudes and attributional style. International Journal of Psychology, 39(4), 245-253. https://doi.org/10.1080/00207590444000005

Chiu, C. M., Wang, E. T. G., Fang, Y. H., \& Huang, H. Y. (2014). Understanding customers' repeat purchase intentions in $\mathrm{B} 2 \mathrm{C}$ e-commerce: The roles of utilitarian value, hedonic value and perceived risk. Information Systems Journal, 24(1), 85-114. https://doi.org/10.1111/j.13652575.2012.00407.x

Connell, C. (2010). Doing, Undoing, or Redoing Gender? Gender \& Society, 24(1), 31-55. 
https://doi.org/10.1177/0891243209356429

Corbin, J. M., \& Strauss, A. (1990). Grounded theory research: Procedures, canons, and evaluative criteria. Qualitative Sociology, 13(1), 3-21. https://doi.org/10.1007/BF00988593

Courtice, E. L., \& Shaughnessy, K. (2017). Technology-mediated sexual interaction and relationships: a systematic review of the literature. Sexual and Relationship Therapy, 32(3-4), 269-290. https://doi.org/10.1080/14681994.2017.1397948

Crocker, J., \& Knight, K. M. (2005). Contingencies of Self-Worth. Current Directions in Psychological Science, 14(4), 200-203. https://doi.org/10.1111/j.0963-7214.2005.00364.x

Crotti, R., Geiger, T., Ratcheva, V., \& Zahidi, S. (2019). Insight Report Global Gender Gap Report. World Economic Forum. www.weforum.org

Edgell, P. (2005). Religion and family in a changing society. In P. Edgell (Ed.), Religion and Family in a Changing Society. Princeton University Press. https://doi.org/10.1093/socrel/srp025.

Eid, R. (2005). International internet marketing: a triangulation study of drivers and barriers in the business-to-business context in the United Kingdom. Marketing Intelligence \& Planning, 23 (3) : 266-280.

Eid, R., Trueman, M., 2002. The internet: new international marketing issues. Management Research News, 25 (12): 54-67.

El-Bassiouny, N. (2015). Where is "Islamic marketing" heading? Journal of Business Research, 69(2), 569-578. https://doi.org/10.1016/j.jbusres.2015.05.012

Elliott, R. (2014). Symbolic Meaning and Postmodern Consumer Culture. In D. Brownlie, M. Saren, R. Wensley, R. Whittington, \& R. Elliott (Eds.), Rethinking Marketing: Towards Critical Marketing Accountings (pp. 112-125). SAGE Publications Ltd. https://doi.org/10.4135/9781446280058.n8

Feather, N. T. (1964). Acceptance and rejection of arguments in relation to attitude strength, critical ability, and intolerance of inconsistency. Journal of Abnormal and Social Psychology, 69(2), 127-136. https://doi.org/10.1037/h0046290

Goffman, E. (1984). Stigma and Social Identity. In A. Blaikie, M. Hepworth, M. Holmes, A. Howson, \& S. Sartain (Eds.), The Body: Critical Concepts in Sociology (Vol. 1, pp. 116-132). Routledge.

Gollnhofer, J. (2015). Taste the Waste - Constructing New Moralities Through Taboo Consumption. In K. Diehl, C. Yoon, \& M. Duluth (Eds.), Advances in Consumer Research Volume (Vol. 43, pp. 542-548). Association for Consumer Research.

Goren, P., Federico, C. M., \& Kittilson, M. C. (2009). Source Cues , Expression Partisan Identities , and Political Value of Minnesota. American Journal of Political Science, 53(4), 805-820.

Greenberg, J. (2014). Obeidallah: Saudi Arabia is the only Muslim nation where women can't drive. PolitiFact. https://www.politifact.com/factchecks/2014/oct/07/dean-obeidallah/obeidallah-saudiarabia-only-muslim-nation-where-w/

Guba, E. G. (1981). Criteria for Assessing the Trustworthiness of Naturalistic Inquiries. Educational Communication and Technology Journal, 29(2), 75-91.

Hemetsberger, A., \& Weinberger, R. (2012). In pursuit of being different. Advances in Consumer Research, 40, 502-509.

Hirschman, E. C. (1991). Exploring the Dark Side of Consumer Behavior: Methaphor and Ideology in Prostitution and Pornography. In J. Costa (Ed.), Advances in Consumer Research (Vol. 36, pp. 303-314). Association for Consumer Research.

Hoek, J. (2004). Tobacco promotion restrictions: Ironies and unintended consequences. Journal of Business Research, 57(11), 1250-1257. https://doi.org/10.1016/S0148-2963(02)00449-6

Hofacker, C. (2001). Internet Marketing, 3rd Edition (3rd ed.). John Wiley \& Sons, Inc.

Hogg, M. A., Adelman, J. R., \& Blagg, R. D. (2010). Religion in the face of uncertainty: An uncertainty-identity theory account of religiousness. Personality and Social Psychology Review, 14(1), 72-83. https://doi.org/10.1177/1088868309349692

Holbrook, M. B., \& Hirschman, E. C. (1982). The Experiential Aspects of Consumption: Consumer 
Fantasies, Feelings, and Fun. Journal of Consumer Research, 9(2), 132-142. https://doi.org/10.1086/208906

Hong, S.-M., Giannakopoulos, E., Laing, D., \& Williams, N. A. (1994). Psychological reactance: Effects of age and gender. The Journal of Social Psychology, 134(2), 223-228.

Hood Jr, R. W., Spilka, B., Hunsberger, B., \& Gorsuch, R. (1996). Religion, coping, and adjustment. The Psychology of Religion: An Empirical Approach, 377-405.

Jafari, A., \& Sandikci, Ö. (2016). The ontological pitfalls of Islamic exceptionalism: A re-inquiry on El-Bassiouny's $(2014,2015)$ conceptualization of "Islamic marketing." Journal of Business Research, 69(3), 1175-1181. https://doi.org/10.1016/j.jbusres.2015.09.016

Jafari, A., \& Süerdem, A. (2012). An analysis of material consumption culture in the Muslim world. Marketing Theory, 12(1), 61-79. https://doi.org/10.1177/1470593111424184

Ji, M. F., \& Wood, W. (2007). Purchase and consumption habits: Not necessarily what you intend. Journal of Consumer Psychology, 17(4), 261-276. https://doi.org/10.1016/S10577408(07)70037-2

Jost, J. (2020). A Theory of System Justification (Vol. 1). Harvard University Press. https://www.hup.harvard.edu/catalog.php?isbn=9780674244658

Jost, J., \& Hunyady, O. (2003). The psychology of system justification and the palliative function of ideology. European Review of Social Psychology, 13(1), 111-153.

Kay, A. C., Gaucher, D., Peach, J. M., Laurin, K., Friesen, J., Zanna, M. P., \& Spencer, S. J. (2009). Inequality, Discrimination, and the Power of the Status Quo: Direct Evidence for a Motivation to See the Way Things Are as the Way They Should Be. Journal of Personality and Social Psychology, 97(3), 421-434. https://doi.org/10.1037/a0015997

Keizer, J. (2017). Business Research Projects. In Business Research Projects. Cengage Learning EMEA. https://doi.org/10.4324/9780080459691

Khare, A., Parveen, C., \& Mishra, A. (2012). Influence of normative and informative values on fashion clothing involvement of Indian women. Journal of Customer Behaviour, 11(1), 9-32. https://doi.org/10.1362/147539212x13286273975193

King, J. E., \& Crowther, M. R. (2004). The measurement of religiosity and spirituality: Examples and issues from psychology. Journal of Organizational Change Management, 17(1), 83-101. https://doi.org/10.1108/09534810410511314

Kirk, J., \& Miller, M. (1986). Reliability and Validity in Qualitative Research (1st ed.). Sage Publication.

Knight, C. G., Tobin, S. J., \& Hornsey, M. J. (2014). From fighting the system to embracing it: Control loss promotes system justification among those high in psychological reactance. Journal of Experimental Social Psychology, 54(0), 139-146. https://doi.org/10.1016/j.jesp.2014.04.012

Kraft, Pål, Rise, Jostein, Sutton, \& Stephen. (2005). Perceived difficulty in the theory of planned behaviour: Perceived. Espen The British Journal of Social Psychology Psychology Database, 44(3), 479-496.

Laurin, K., Kay, A. C., \& Fitzsimons, G. J. (2012). Reactance versus rationalization: divergent responses to policies that constrain freedom. Psychological Science, 23(2), 205-209. https://doi.org/10.1177/0956797611429468

Laurin, K., Kay, A. C., Proudfoot, D., \& Fitzsimons, G. J. (2013). Response to restrictive policies: Reconciling system justification and psychological reactance. Organizational Behavior and Human Decision Processes, 122(2), 152-162. https://doi.org/10.1016/j.obhdp.2013.06.004

Laurin, K., Spencer, S. J., Gaucher, D., Zanna, M. P., Peach, J. M., Friesen, J., \& Kay, A. C. (2009). Inequality, discrimination, and the power of the status quo: Direct evidence for a motivation to see the way things are as the way they should be. Journal of Personality and Social Psychology, 97(3), 421-434. https://doi.org/10.1037/a0015997

Li, J., Abbasi, A., Cheema, A., \& Abraham, L. B. (2020). Path to Purpose? How Online Customer Journeys Differ for Hedonic Versus Utilitarian Purchases. Journal of Marketing, 84(4), 127146. https://doi.org/10.1177/0022242920911628 
Lim, W. M. (2015). Enriching information science research through chronic disposition and situational priming: A short note for future research. Journal of Information Science, 41(3), 399-402. https://doi.org/10.1177/0165551515577913

Lim, W. M. (2018). Demystifying neuromarketing. Journal of Business Research, 91, 205-220. https://doi.org/10.1016/j.jbusres.2018.05.036

Lim, W. M., Ahmed, P. K., \& Ali, M. Y. (2019). Data and resource maximization in business-tobusiness marketing experiments: Methodological insights from data partitioning. Industrial Marketing Management, 76, 136-143. https://doi.org/10.1016/J.INDMARMAN.2018.08.007

Lincoln, Y. S., \& Guba, E. G. (1990). Judging the quality of case study reports. International Journal of Qualitative Studies in Education, 3(1), 53-59. https://doi.org/10.1080/0951839900030105

Liu, Y., \& Tang, X. (2018). The effects of online trust-building mechanisms on trust and repurchase intentions: An empirical study on eBay. Information Technology and People, 31(3), 666-687. https://doi.org/10.1108/ITP-10-2016-0242

Lusch, R. F., \& Vargo, S. L. (2011). Service-dominant logic: A necessary step. European Journal of Marketing, 45(7), 1298-1309. https://doi.org/10.1108/03090561111137723

Maher, C., Hadfield, M., Hutchings, M., \& de Eyto, A. (2018). Ensuring Rigor in Qualitative Data Analysis. International Journal of Qualitative Methods, 17(1), 160-173. https://doi.org/10.1177/1609406918786362

Manceau, D., \& Tissier-Desbordes, E. (2006). Are sex and death taboos in advertising?: An analysis of taboos in advertising and a survey of French consumer perceptions. International Journal of Advertising, 25(1), 9-33. https://doi.org/10.1080/02650487.2006.11072949

Mano, P. (2021). Virtual Activism: Sexuality, the Internet, and a Social Movement in Singapore, by Robert Phillips. Anthropologica, 63(1). https://doi.org/10.18357/anthropologica6312021342

Marshall, C., \& Rossman, G. (1999). Interpretive Interactionism.Participant Observation: A Methodology for Human Studies.Designing Qualitative Research. Journal of Marketing Research, 27(3), 21-54. https://doi.org/10.2307/2072869

Miranda, J. A. (2020). The country-of-origin effect and the international expansion of Spanish fashion companies, 1975-2015. Business History, 62(3), 488-508. https://doi.org/10.1080/00076791.2017.1374370

Moore, S. G., \& Fitzsimons, G. J. (2014). Yes, we have no bananas: Consumer responses to restoration of freedom. Journal of Consumer Psychology, 24(4), 541-548. https://doi.org/10.1016/j.jcps.2014.04.001

Morris, M. W., \& Liu, Z. (2015). Psychological Functions of Subjective Norms. Journal of CrossCultural Psychology, 46(10), 1279-1287. https://doi.org/10.1177/0022022115612161

Owuamalam, C. K., \& Spears, R. (2020). Do humans possess an autonomous system justification motivation? A Pupillometric test of the strong system justification thesis. Journal of Experimental Social Psychology, 86, 103897. https://doi.org/10.1016/j.jesp.2019.103897

Passyn, K. A., Diriker, M., \& Settle, R. B. (2011). Images Of Online Versus Store Shopping: Have The Attitudes Of Men And Women, Young And Old Really Changed? Journal of Business \& Economics Research, 9(1), 210-232. https://doi.org/10.19030/jber.v9i1.946

Petriglieri, G. (2020). A Psychodynamic Perspective on Identity as Fabrication. In A. Brown (Ed.), The Oxford Handbook of Identities in Organizations (pp. 121-132). Oxford Press. https://doi.org/10.1093/OXFORDHB/9780198827115.013.22

Pezzuti, T., Pirouz, D., \& Pechmann, C. (2015). The effects of advertising models for age-restricted products and self-concept discrepancy on advertising outcomes among young adolescents. Journal of Consumer Psychology, 25(3), 519-529. https://doi.org/10.1016/j.jcps.2015.01.009

Picot-Coupey, K., Krey, N., Huré, E., \& Ackermann, C. L. (2021). Still work and/or fun? Corroboration of the hedonic and utilitarian shopping value scale. Journal of Business Research, 126, 578-590. https://doi.org/10.1016/j.jbusres.2019.12.018

Piha, S., Hurmerinta, L., Sandberg, B., \& Järvinen, E. (2018). Journal of Marketing Management From filthy to healthy and beyond: finding the boundaries of taboo destruction in sex toy 
buying. Journal of Marketing Management, 34, 1078-1104. https://doi.org/10.1080/0267257X.2018.1496946

Pratt, M. W., Hunsberger, B., Lea, J., Pancer, S. M., \& Jackson, L. M. (2006). Religious Orthodoxy and the Complexity of Thought about Religious and Nonreligious Issues. Journal of Personality, 63(2), 213-232. https://doi.org/10.1111/j.1467-6494.1995.tb00808.x

Reichertz, J. (2007). Logic of discovery of grounded theory. In The Sage handbook of grounded theory. Sage.

Richards, L. (2013). Ecommerce stats: online shopping in the Middle East . Econsultancy. https://econsultancy.com/ecommerce-stats-online-shopping-in-the-middle-east/

Sabri, O. (2017). Does Viral Communication Context Increase the Harmfulness of Controversial Taboo Advertising? Journal of Business Ethics, 141(2), 235-247. https://doi.org/10.1007/s10551-015-2751-9

Sabri, O., Manceau, D., \& Pras, B. (2010). Taboo: An Underexplored Concept in Marketing. Recherche et Applications En Marketing (English Edition), 25(1), 59-85. https://doi.org/10.1177/205157071002500103

Sabri, O., \& Obermiller, C. (2012). Consumer perception of taboo in ads. Journal of Business Research, 65(6), 869-873. https://doi.org/10.1016/j.jbusres.2011.01.009

Salciuviene, L., Ghauri, P. N., Streder, R. S., \& De Mattos, C. (2013). Do brand names in a foreign language lead to different brand perceptions? Multicultural Perspectives in Customer Behaviour, 26(11), 45-64. https://doi.org/10.4324/9780203722411

Saroglou, V. (2002). Religion and the five factors of personality: A meta-analytic review. Personality and Individual Differences, 32(1), 15-25. https://doi.org/10.1016/S0191-8869(00)00233-6

Scarpi, D. (2020). Hedonism, Utilitarianism, and Consumer Behavior. In Hedonism, Utilitarianism, and Consumer Behavior. Palgrave Macmillan. https://doi.org/10.1007/978-3-030-43876-0

Scarpi, D., Pizzi, G., \& Visentin, M. (2014). Shopping for fun or shopping to buy: Is it different online and offline? Journal of Retailing and Consumer Services, 21(3), 258-267. https://doi.org/10.1016/j.jretconser.2014.02.007

Sebald, A. K., \& Jacob, F. (2020). What help do you need for your fashion shopping? A typology of curated fashion shoppers based on shopping motivations. European Management Journal, 38(2), 319-334. https://doi.org/10.1016/j.emj.2019.08.006

Slater, D. (1997). Consumer culture and modernity. (1st ed.). Polity Press.

Snibbe, A. C., \& Markus, H. R. (2005). You can't always get what you want: Educational attainment, agency, and choice. Journal of Personality and Social Psychology, 88(4), 703-720. https://doi.org/10.1037/0022-3514.88.4.703

Stafford, T. F., Turan, A. H., \& Raisinghani, M. S. (2004). International and cross-cultural influences on online shopping behavior. Journal of Global Information Technology Management, 7(2), 7087. https://doi.org/10.1080/1097198X.2004.10856373

Tannenbaum, P. H., \& Osgood, C. E. (1955). The principle of congruity in the prediction of attitude change. Psychological Review, 62(1), 42-55.

To, P. L., Liao, C., \& Lin, T. H. (2007). Shopping motivations on Internet: A study based on utilitarian and hedonic value. Technovation, 27(12), 774-787. https://doi.org/10.1016/j.technovation.2007.01.001

Torrance, E. P., \& Brehm, J. W. (1968). A Theory of Psychological Reactance. The American Journal of Psychology, 81(1), 133-152. https://doi.org/10.2307/1420824

Van Hiel, A., Pandelaere, M., \& Duriez, B. (2004). The impact of need for closure on conservative beliefs and racism: Differential mediation by authoritarian submission and authoritarian dominance. Personality and Social Psychology Bulletin, 30(7), 824-837. https://doi.org/10.1177/0146167204264333

Variyar, M. (2015). Saudi Arabi Bans Fashion Shows. http://www.ibtimes.co.in/saudi-arabia-bansfashion-shows-634628

Veer, E., \& Golf-Papez, M. (2018). Physically freeing: breaking taboos through online displays of 
the sexual self. Journal of Marketing Management, 34(13-14), 1105-1125. https://doi.org/10.1080/0267257X.2018.1484381

Venkatesan, M. (1966). Experimental Study of Consumer Behavior Conformity and Independence. Journal of Marketing Research, 3(4), 384-387. https://doi.org/10.1177/002224376600300407

Wicklund, J., \& Brehm, W. (1967). Perspectives on Cognitive Dissonance. Lawrence Erlbaum Associates, Inc.

Wicklund, R. A. (2013). Perspectives on Cognitive Dissonance. In Perspectives on Cognitive Dissonance. Psychology Press. https://doi.org/10.4324/9780203767672

Wolfinbarger, M., \& Gilly, M. C. (2001). Shopping Online for Freedom, Control, and Fun. California Management Review, 43(2), 34-55. https://doi.org/10.2307/41166074

Woller, K. M. P., Buboltz, W. C., \& Loveland, J. M. (2007). Psychological reactance: Examination across age, ethnicity, and gender. American Journal of Psychology, 120(1), 15-24. https://doi.org/10.2307/20445379

Wu, W., Huang, V., Chen, X., Davison, R. M., \& Hua, Z. (2018). Social value and online social shopping intention: the moderating role of experience. Information Technology and People, 31(3), 688-711. https://doi.org/10.1108/ITP-10-2016-0236

Xu, Y., \& Paulins, V. A. (2005). College students' attitudes toward shopping online for apparel products. Exploring a rural versus urban campus. Journal of Fashion Marketing and Management, 9(4), 420-433. https://doi.org/10.1108/13612020510620795

Yalkin, C., \& Veer, E. (2018). Taboo on TV: gender, religion, and sexual taboos in transnationally marketed Turkish soap operas. Journal of Marketing Management, 34(13-14), 1149-1171. https://doi.org/10.1080/0267257X.2018.1520738 
Dear Editor,

We appreciate and acknowledge the value of all comments received. We believe that these profound and opening-eyes comments helped us frame this paper to be like this. All the eight reviewers illuminated us with critical remarks over the two years, which were helpful and supportive. We acknowledge and thank them for all of their outstanding efforts to help us make the paper to be as it is now. Without their comments, we believe this manuscript would not be as convincing and consistent now. We are delighted to accept all the comments in this round. We hope the paper is ready now for publication.

Best Regards, Authors

First Reviewer,

We are very grateful for your feedback during the last two iterations. We are delighted to know that you have accepted the paper for publication. We have to confess without your valuable comments, and the article would not be like this.

Second Reviewer,

Thank you for your constructive and helpful comments. We accept all of them, and we believe in their merits. We worked hard to address all of your excellent and opening-eyes feedbacks.

\begin{tabular}{|l|l|}
\hline Comment & Response \\
\hline $\begin{array}{l}\text { Thank you for revising the paper. I } \\
\text { appreciate that the core topic is research- } \\
\text { worthy and that the findings from your } \\
\text { study are relatively clear. Overall, I found } \\
\text { the paper engaging and the topic worthy of } \\
\text { further examination. I am very interested in } \\
\text { how digital technology, i.e. online shopping, } \\
\text { affects consumers' behaviours for taboo } \\
\text { products. I take a developmental perspective } \\
\text { for the review and hope it helps to clarify } \\
\text { any possible issues. }\end{array}$ & \\
\hline $\begin{array}{l}\text { The paper does address a little-studies area } \\
\text { from an interesting perspective; however, } \\
\text { given the nascent and sensitive nature of the } \\
\text { topic, a well-elaborated research context and } \\
\text { a well-justified motivation is a necessity. I } \\
\text { understand the author/s has taken the time } \\
\text { and efforts to further build up the bits, but } \\
\text { the current version does not provide an } \\
\text { explicit and convincing ground to present } \\
\text { the work. To be specific, the detailed } \\
\text { context, in which the research was }\end{array}$ & $\begin{array}{l}\text { We agree with you! Because we are too much in the } \\
\text { added this paragraph in the introduction section to } \\
\text { give a quick overview of the context. }\end{array}$ \\
& $\begin{array}{l}\text { Religious restrictions are unlike any of these, } \\
\text { especially if state agents enforce them. The case for } \\
\text { a religious state which presents itself as ruling in the } \\
\text { name of God is different from any discussed in the } \\
\text { previous literature. Saudi Arabia established } \\
\text { religious police to enforce in public the practice of }\end{array}$ \\
\hline
\end{tabular}


conducted and the data collection was undertaken, is largely missing from the narratives. There are some descriptions regarding the specific taboo targeted in the focal case, but they are provided in a sporadic manner, which is very difficult to follow, especially to the readers without prior knowledge. As a result, it has weakened the research motivation, as the contextual motive failed to resonate with readers. Further, despite the author/s' efforts on further strengthening the reasons for the research, the theoretical aspect is not convincingly linked to the context. This is particularly obvious when the author/s suggested "disobeying the religious orders has not been studied before in the literature" (L45/46, P3), as the linkage between such with SJT and PRT seems rather unclear. In sum, I would recommend the author/s to revisit the research context and motivation to properly justify the research.

The literature review is well structured as the author/s examined the online shopping motivation in general and then narrowed down to motivations in taboo shopping online. However, the research gap (L6-9, P6) was presented in an isolated manner as how this is particularly linked to the focal case, and in which specific aspect, the current work failed to shed light on? My concern is that the current research gap is a bit general to fully situate the research question.

I understand the sensitive nature the research topic locally, but just because of this, the process needs to be detailed to fully justify the research and its rigour.
Islamic values such as gender segregation in workplaces and shops, ways of dressing in public, opening and closing times for shops (e.g., the specific times for prayer each day), what fashions may be sold in shops and how they may be sold. The risk of disobeying the state's religious orders could have a more substantial influence on human behaviour than the risk in a secular state.

We also added a whole section called (Background) to portray the context for the reader and explain the state religious restrictions. Also, the roots of these religious restrictions and how this context is unique. This new section ends by this paraph

This context of study offers a rich environment for understanding the actions of the state in enforcing a level of religious policing that affects the freedom of women to dress and choose for themselves what to wear. Online shopping may be a vehicle by which this religious-state restrictions may be justified or it may be reacted against by buying online from Western countries. The present research offers a new perspective from which to understand this unique location-based taboo market (i.e. it is forbidden in Saudi Arabia but allowed everywhere else in the world) and define the motivations of its online shoppers in using technology.

\footnotetext{
We have re-written the sampling section. Also we added two paragraphs to detail the process and justify the rigorousness of the research.

Second, the criteria for selection of the sample and its size were set by the iterative nature of the data collection and analysed by theoretical sampling (Corbin \& Strauss, 1990). The sample does not represent the Saudi population. The purpose was to recruit women from a restrictive society who had the means and ability to shop online, for a qualitative investigation of their attitudes to online shopping. The population targeted in this research was Saudi women resident in Saudi Arabia, able to
} 
buy fashion online without restrictions of a psychological nature (trust in online shopping; perceived difficulties in buying fashion online) or a material nature (shipping or payment problems). Men were excluded because women face considerably more restrictions, specifically in the choice of clothing (Al-Rasheed, 2013). The age range (30-49) was selected to exclude both young and old people. Older people are more inclined to justify the status quo (Laurin et al., 2009), while teenagers and young women may be effectively controlled by their families or unduly sensitive to peer pressure (imitating friends, celebrities or fashion icons) in their fashion behaviour (Khare et al., 2012). All the recruits had experience of online shopping and bought clothes and other items online. None had any technical or trust issue with online shopping; it is known that the propensity to trust (Liu \& Tang, 2018) and perception of difficulty (Kraft et al., 2005) in using online shopping can affect attitudes and motivation. To ensure consistency and avoid the effects on attitude of living in remote or rural areas (Xu \& Paulins, 2005), all the interviews were conducted in Riyadh (the capital city of Saudi Arabia).

\section{We also added this paragraph}

Fourth, the sampling recruitment process was based on snowball sampling. Because of the nature of this research project, the writers could not use public websites to recruit participants; rather, personal networks were used, and respondents were asked to refer the project to others who might fit the research needs. The second author, who lives in Saudi Arabia, approached women whom she personally knew or who had been referred by other interviewees. She gave them a consent form stating that the identity of the respondents would never be by any means disclosed. The researcher gave code names to these respondents before sharing the transcripts with the other researchers. Despite respondents being assured of their anonymity, three women refused to complete the interview. One claimed that the researcher was working for the government's intelligence system and left without completing her interview. The other interviewees were eventually satisfied and completed their interviews without further demur, having been given confidence that the second researcher would 


\begin{tabular}{|l|l|}
\hline & $\begin{array}{l}\text { not disclose their identity. } \\
\text { The interviews were conducted in Arabic and } \\
\text { analysed in Arabic because all the researchers, } \\
\text { except the last one, are bi-lingual (Arabic and } \\
\text { English). English was not used because the } \\
\text { interviews were held in Saudi Arabia where the } \\
\text { mother tongue is Arabic. The aim was for them to } \\
\text { express their opinions freely without language } \\
\text { restrictions. Moreover, translation before the final } \\
\text { reporting of the analytical results could have } \\
\text { affected the quality of the analysis since meaning } \\
\text { typically alters to some extent in translation. }\end{array}$ \\
\hline $\begin{array}{l}\text { The illustrative coding summary is } \\
\text { recommended to be added and presented in } \\
\text { the Section of results, which will help } \\
\text { readers to follow the storyline. Figure 2 is a } \\
\text { bit descriptive in general, not necessarily } \\
\text { reflecting the abstract connotations of the } \\
\text { codes. More information is needed to } \\
\text { provide the ground on which the four types } \\
\text { of behaviours were formulated. }\end{array}$ & $\begin{array}{l}\text { We added a new section and a new diagram to } \\
\text { illustrate the coding summary (Table 4). Also, we } \\
\text { now introduced the codes to make figure 2 easier to } \\
\text { read and to follow. }\end{array}$ \\
\hline $\begin{array}{l}\text { Are these implications consistent with the } \\
\text { findings and conclusions of the paper?: The } \\
\text { paper identified both theoretical and } \\
\text { practical implications. }\end{array}$ & $\begin{array}{l}\text { We are pleased to know that the theoretical and } \\
\text { practical implications are good. }\end{array}$ \\
\hline $\begin{array}{l}\text { Has attention been paid to the clarity of } \\
\text { expression and readability, such as sentence } \\
\text { structure, jargon use, acronyms, etc: There } \\
\text { are numerous grammar mistakes and/or } \\
\text { typos in the article, which needs a thorough } \\
\text { proofreading. }\end{array}$ & $\begin{array}{l}\text { We sent the paper to a professional native English } \\
\text { speaker proof-reader }\end{array}$ \\
\hline
\end{tabular}

